PROCEEDINGS OF THE UNITED STATES NATIONAL MUSEUM

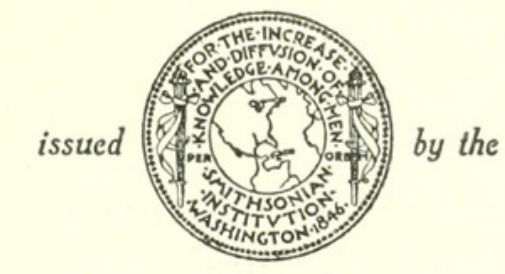

SMITHSONIAN INSTITUTION

U. S. NATIONAL MUSEUM

\title{
A REVISION OF THE EELS OF THE GENUS CONGER WITH DESCRIPTIONS OF FOUR NEW SPECIES
}

\section{By Robert H. Kanazawa}

This study redefines the genus Conger Oken and describes 14 species, with 2 subspecies. The leptocephalus larvae referred to this genus were excluded from this study.

The most important studies of the genus were by Kaup $(1856 a, b)$, who distinguished nine species. Günther (1870) recognized four species, but included in vulgaris forms from almost the whole world and since then many authors have followed his conclusions.

Subsequent authors have made studies on a regional basis: Jordan and Davis (1892) referred the three Atlantic species to Leptocephalus Gronovius, instead of Conger; Jordan and Evermann (1896) combined the conger eels of the Americas and Europe into two species under Leptocephalus; Jordan and Snyder (1901) recognized seven species in Leptocephalus from Japanese waters; Evermann and Kendall (1906) concluded that $C$. orbignyanus Castelnau from South America is distinct from North American species; Weber and de Beaufort (1916) distinguished but two species in Conger and included with C. conger forms from all over the world; Jordan and Hubbs (1925) placed two species from Japan in Conger and erected the new genus Astroconger for myriaster; Griffin's (1936) revision of New Zealand 
eels lists two species; Ginsburg (1951), following Jordan and Evermann (1896), synonymized Ariosoma Swainson and Ophiosoma Swainson with Conger and distinguished two species from the Western North Atlantic.

The specimens in the collections of the following institutions form the basis of this study: American Museum of Natural History (AMNH), Academy of Natural Sciences of Philadelphia (ANSP), Chicago Natural History Museum (CNHM), George Vanderbilt Foundation (GVF), Museum of Comparative Zoology, Harvard University (MCZ), Stanford Natural History Museum (SNHM), University of Michigan, Museum of Zoology (UMMZ), and U. S. National Museum (USNM).

I wish to acknowledge my thanks to the authorities of the above mentioned institutions for the loan of specimens and to the following individuals: Dr. L. P. Schultz and Dr. E. A. Lachner of the U. S. National Museum for their kind help and advice; Dr. J. Böhlke, Academy of Natural Sciences of Philadelphia; Dr. L. Bertin, Museum National d'Histoire Naturelle, Paris; Dr. N. B. Marshall, British Museum (Natural History), Dr. T. Kamohara, Kochi University, Japan; and W. C. Schroeder, Museum of Comparative Zoology, for meristic counts, measurements, and information on types deposited in their collections; Dr. and Mrs. J. L. B. Smith for specimens from South Africa; Dr. R. Zangerl, Chicago Natural History Museum; the X-ray laboratory staff of the Federal Bureau of Investigation, Washington, D. C., for radiographs used in vertebral counts; and the Smithsonian Institution's photographic laboratory for numerous photographs.

Procedures: The total length and distance from tip of snout to anus were taken by extending the specimens on a table and sticking a pin into the table at the tip of snout, anus, and tip of caudal fin; the distances between the pins then were measured. All other measurements were made with a vernier caliper to the nearest one-tenth of a millimeter. The length of head was measured from tip of snout to upper edge of gill opening; distance from origin of dorsal fin to insertion of pectoral fin was measured between a line drawn from the insertion of the left pectoral fin to the insertion of the right fin and a vertical line was drawn from this line to the origin of dorsal fin. The longest pectoral fin was measured. All measurements are expressed in thousandths of total length except the distance from tip of pectoral fin to origin of dorsal fin, which is expressed in percent of pectoral fin length. Lateral line pores were counted in front of a perpendicular line through anus. The pectoral rays were counted after the skin was dissected from the bases of these rays, otherwise the small rays at the ventral edge of the fin base might have been 
overlooked. All of the compressed teeth in the outer row of one half of the upper jaw were counted. The first vertebra that has a complete haemal arch was counted as the first caudal vertebra.

Quantitative characters which are diagnostic on a subspecies level are presented graphically in figure 3, following the methods of Hubbs and Hubbs (1953, p. 51).

\section{Diagnostic Characters}

ORIGIN OF DORSAL FIN: The congers can roughly be separated into three groups on the basis of the position of the origin of dorsal fin: (1) species with origin of dorsal fin anterior to pectoral fin tipcinereus, erebennus, and myriaster; (2) species with origin of dorsal fin posterior to tip of pectoral fin-jordani, orbignyanus, wilsoni, and philippinus; and (3) species with origin of dorsal fin above posterior tip of pectoral fin-all the remaining species. There is great variation within species and considerable overlap among some species in regard to this character; however, within limits of variation, it is of importance (table 1). Previously the origin of dorsal fin in relation to pectoral fin tip had been the main character for distinguishing species.

Pectoral fin Rays: The range of variation for all species is from 14 to 21 rays, but for a single species only 4 to 5 rays (table 2 ).

Vertebrae: The range of variation of the number of vertebrae (table 3) is from 127 to 163 , with philippinus and esculentus on the lower end of this range and orbignyanus, conger, verreauxi, and triporiceps on the upper end. Great care must be taken in order to recognize eels with regenerated tails for they have great powers of forming new ones; however, new vertebrae are not regenerated. The joining of the new caudal fin with the dorsal and anal ins is so well blended at times that it is difficult to distinguish some specimens with regenerated tails.

Sensory pores and organs: The sensory pores of the lateral line and cephalic pore systems provide characters which differ in several species. The terminology used in the description is shown in figure $1 \mathrm{~A}-\mathrm{C}$ and was adapted from Allis (1903). The external pores on the head open directly into a pouchlike tube (y) which connects it with the lateral sensory canal; however, some of these pouches lack this external opening. There are generally six infraorbital pores in the genus; however, two species, cinereus and triporiceps have an additional one to three more pores in the postorbital series which is the dorsal extension of the infraorbital series $\left(i^{7}, i^{8}, i^{9}\right)$. All the species have the sixth infraorbital pore directly behind the rictus of jaw except cinereus, which has it above and behind the rictus (c). All the 
species have two ethmoidal pores at tip of snout. The second ethmoidal pore is fused with the first supraorbital pore to form a single exterior pore $\left(\mathrm{e}^{2} \mathrm{~S}^{1}\right)$. Generally two supraorbital pores occur on the snout, $\left(\mathrm{S}^{1}, \mathrm{~S}^{2}\right)$; however, only four are present in triporiceps $\left(\mathrm{S}^{1}, \mathrm{~S}^{2}\right.$, $\left.\mathrm{S}^{3}, \mathrm{~S}^{5}\right)$. There are 9 to 11 preoperculo-mandibular pores present: cinereus has 10 (11th missing), triporiceps has 11, orbignyanus has 9 or 10 , and all others have $9\left(\mathrm{pm}^{7}, \mathrm{pm}^{11}\right.$ missing). There is generally one supratemporal pore (st) in the genus, but only triporiceps has three. The range of variation interspecifically for the lateral line pores on the body is from 35 to 47 ; the fewest numbers are found in esculentus, oligoporus and macrocephalus and the greatest numbers in orbignyanus and conger (table 2). In addition to these sensory pores, surface sensory organs $(\mathrm{x})$, which are in series, also are developed.

In myriaster these sensory pores and organs are accentuated by a light area surrounding them. Usually this character is important to distinguish this species, but in some old specimens these light areas are not discernible, thus making identifications difficult. See remarks under the species myriaster for further discussion.

Preorbital bone: The shape of the preorbital bone in Conger is significantly different than those of other genera in the family. It is a flat triangular bone, the longest side presented ventrally with a groove at the lower side. The dorsal apex is generally presented toward one side; but in myriaster it is more toward the middle than in other species (pl. 1,A). Conger cinereus (pl. 1,I) shows the greatest ossification, whereas myriaster shows the least. More ossification develops with increased age. In adult triporiceps, wilsoni, and jordani this ossification has bridged over the sensory groove, but in young jordani this ossification has not developed. In erebennus and myriaster this groove is not bridged over by bone even in the largest specimens. Tough connective tissues bridge over this groove in all species, but these tissues were removed to show the underlying ossification.

Dentition: The number of rows of teeth, the number of compressed teeth, and the shape of the vomerine tooth-patch are of importance in distinguishing some species of Conger. One or two rows of teeth occur laterally on the jaws. The outer row is compressed to form a cutting edge. In those species with a single row of teeth, two or three teeth may be found where the inner row would be expected. The inner row in those species with two rows of teeth varies from a few teeth anteriorly in young specimens to almost a complete row in the larger specimens. The number of teeth in the jaws increases directly with age (table 4 and fig. 2). The greatest numbers are found in triporiceps. The vomerine tooth-patch is generally triangular in shape; however, in small triporiceps this patch is a single irregular row and becomes triangular in shape in larger specimens. 

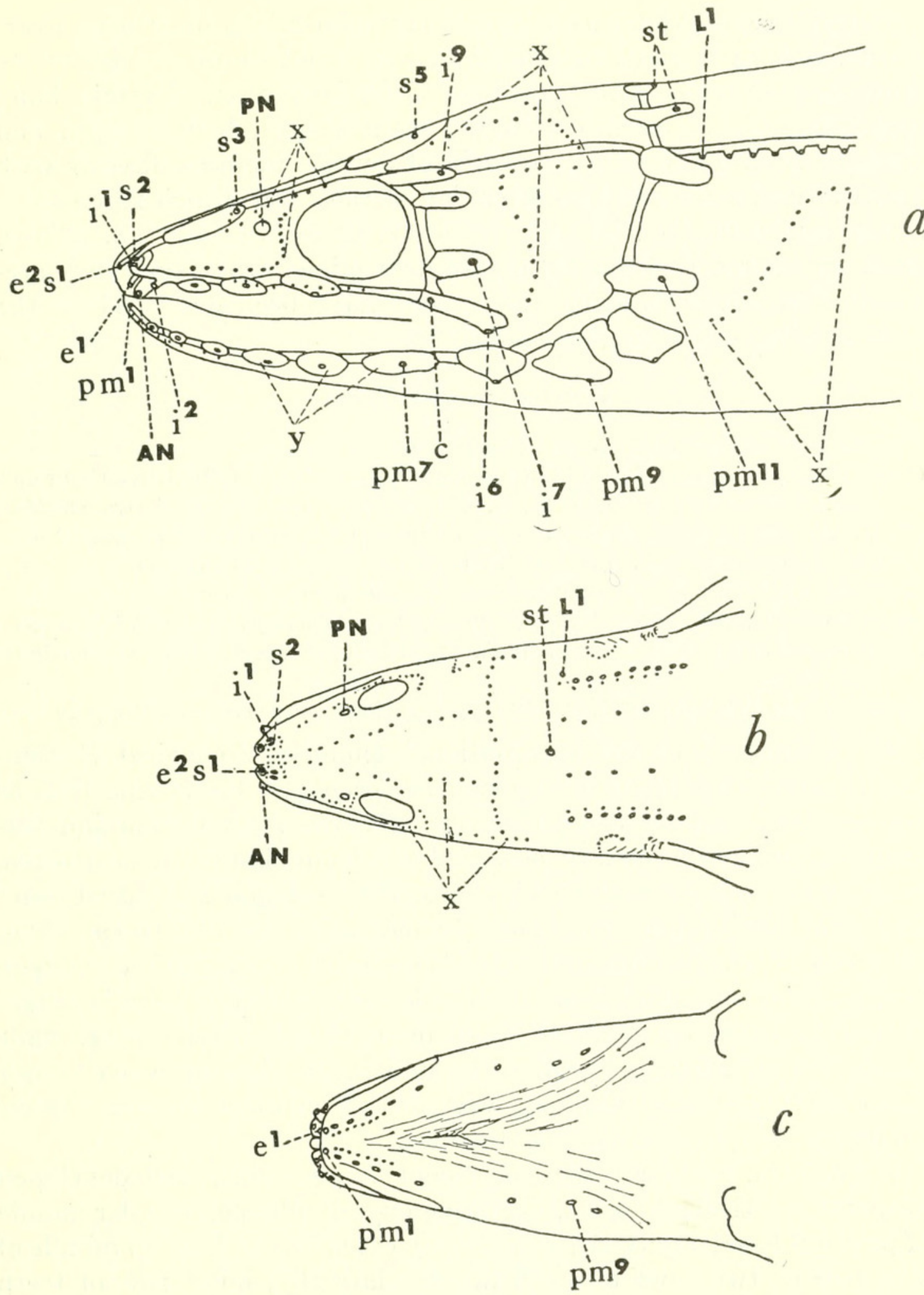

Figure 1.-Views of head of the genus Conger ( $a$, lateral; $b$, dorsal; and $c$, ventral) showing position of surface sensory organs, pores, and sensory pouches. Symbols: AN, anterior nostril; c, position of sixth infraorbital pore for subspecies Conger cinereus cinereus and C. c. marginatus; $\mathrm{e}^{1}$, first ethmoidal pore; $\mathrm{e}^{2} \mathrm{~s}^{1}$, compound pore, second ethmoidal pore, and first supraorbital pore; $\mathrm{i}^{1}$, first infraorbital pore; $\mathrm{L}^{1}$, first lateral line pore; $\mathrm{pm}^{1}$, first preoperculo-mandibular pore; PN, posterior nostril; st, supratemporal pores; $\mathrm{x}$, surface sensory organs; $y$, sensory pouches. (All after Allis, 1903.) 
Proportional measurements: Body proportions have been overemphasized by various authors; however, within limits of variation, they are still important characters in identification. Certain body proportions - such as head length, snout length, body length, and distance from tip of snout to origin of dorsal-increase directly with growth; also, some eels lose a portion of their tail, which regenerates a new caudal fin (but no new vertebrae) to form a new tail. Thus, great errors result when ratios are determined from such measurements. In the past, some new species have been described on the basis of these erroneous measurements.

\section{Genus Conger Oken}

Les Congres Cuvier, 1817, p. 231, vernacular.

Conger Oken, 1817, pp. 1781, 1782 (misprints for pp. 1181, 1182) (Cuvier's French

name Latinized); Bosc, 1817, p. 450; Cuvier, 1834 (English translation),

p. 221 (type species, Muraena conger Linnaeus by absolute tautonomy).

Congrus Richardson, 1844-1848, p. 107 (a variant spelling of Conger).

Isognatha Gill, 1861, p. 56 (type species, Anguilla oceanica Storer).

Microconger Fowler, 1912, p. 9, fig. 1 (type species, Leptocephalus caudalis Fowler). Astroconger Jordan and Hubbs, 1925, p. 194 (type species, Conger myriaster Brevoort).

Forskalichthys Whitley, 1935, p. 219 (type species, Conger cinereus Rüppell).

In Opinion 44 of the International Rules of Zoological Nomenclature, the Commission recognized Leptocephalus Gronovius 1763 as the genus for conger eels; however, in Opinion 93 this action was reversed under the plenary power of the Commission for suspension of the rules and the Commission recognized the genus Conger Cuvier 1817 and designated the name Leptocephalus to the larval form. Direction 87 of the International Commission on Zoological Nomenclature, February 1958, deleted from the official list of generic names in zoology the entry relating to the name Conger Cuvier 1817, made by the ruling given in Opinion 93, and in its place inserted Conger Oken 1817 (gender: masculine), with the type species Muraena conger Linnaeus 1758 , by absolute tautonomy.

Diagnosis: Scaleless, with confluent vertical fins, well developed pectorals, vertical gill cleft wide, upper edge of gill opening near middle of pectoral base; mouth large, maxillary extending at least to middle of eye; one or two rows of teeth in jaws laterally, outer row of teeth compressed, forming a cutting edge; a flat triangular preorbital bone (pl. 1); fingerlike processes in nasal bone; anterior nostrils tubular, posterior nostrils above middle of eye, otic bulla absent, ethmoidal process cartilaginous.

Description: Body formed as in Anguilla, elongate, posteriorly compressed, head depressed; mouth large, maxillary extending at least to below a perpendicular line from middle of eye; origin of dorsal fin above pectoral base to one pectoral length behind posterior tip of 


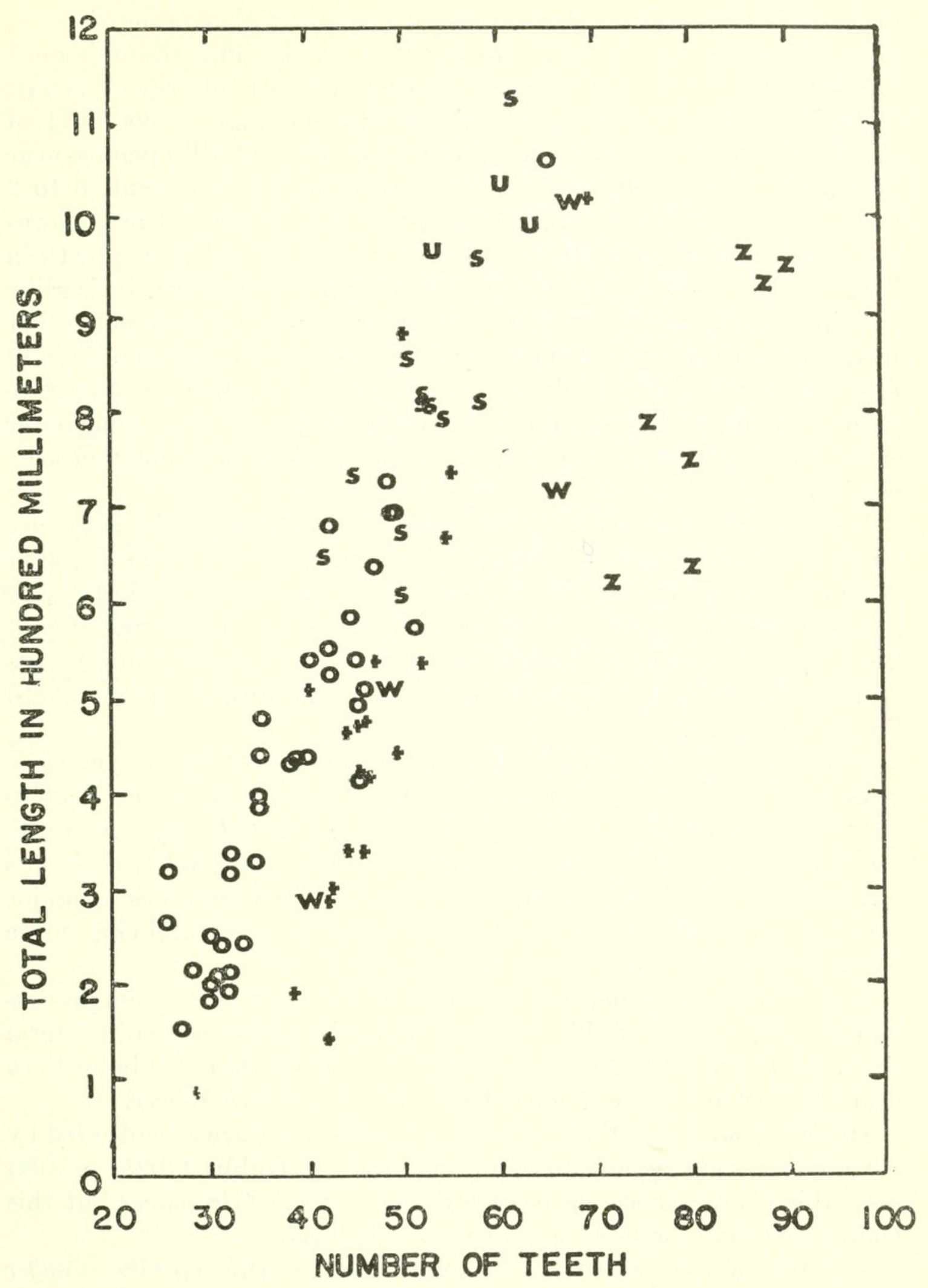

FigURE 2.-Number of compressed teeth in one side of upper jaw for the various species of Conger found in the Atlantic Ocean. Symbols: o, oceanicus; +, conger; s, orbignyanus; $\mathrm{U}$, esculentus; $\mathrm{z}$, triporiceps; and $\mathrm{w}$, wilsoni. 
pectoral fin; lateral line pores present, extending along side of body, pores in lateral line anterior to a perpendicular line through anus number from 30 to 50 ; anterior nostrils tubular at tip of snout; posterior nostrils not tubular adjacent to eye and above level of middle of eye; gill opening large, the upper edge of gill opening near middle of pectoral fin base; sensory pores on head present, 6 to 9 infraorbital pores, 9 to 11 preoperculo-mandibular pores, 1 or 3 supratemporal pores, 2 ethmoidal pores, 2 to 4 supraorbital pores; teeth in jaws in one or two series, outer row of teeth compressed, incisorlike and in contact basally, forming a cutting edge, inner row and other teeth conical, no canines present; anus situated in anterior half of total length; nasal bone thin and translucent with numerous fingerlike structures anteriorly, preorbital bone flat, triangular, overlapping outer surface of the maxillary bone; otic bulla absent; ethmoidal process cartilaginous.

Body uniform brownish or dusky, lighter ventrally, a single species may have wide barring; distal edge of vertical fins black in adult, light in young; black on edge of vertical fins progresses anteriorly with growth; pectorals black or whitish; in young specimens a row of pigment spots are located above base of anal fin and continue across abdomen; as growth progresses these spots diminish in numbers and finally disappear.

Relationship with other genera: The genus Conger has no close relationship to the other genera of the family. Ariosoma, Bathycongrus, Gnathophis, Uroconger, Chiloconger, and Coloconger have the otic bulla, whereas Conger does not. Regan (1912, p. 379), in his classification of the order Apodes, used this character as a major division on a family level. Conger differs further in being more elongate than the forms of the Ariosoma group.

Since Conger caudilimbatus Poey has an otic bulla, ethmoidal process ossified, upper edge of gill opening in line with upper edge of pectoral fin base, preorbital bone not triangular, and body shape stubbier than other species of Conger, I refer it near the genus Chiloconger.

In Conger myriaster the sensory pores and organs are accentuated by a white area surrounding them. Jordan and Hubbs (1925, p. 194) used this character as the basis for a new genus Astroconger but this character should be used only at a specific level.

Species Relationships: Interspecifically the species Conger cinereus shows the greatest degree of differentiation in the barring on body, greater number of infraorbital pores, the higher position of the sixth infraorbital pore, the greatest ossification of the preorbital bone, and the greatest development of the black spot on the pectoral fins. Next, C.triporiceps differs most from all other species by having three supratemporal pores instead of the usual one, seven or eight infraorbital 
pores instead of five, four supraorbital pores instead of the usual two, the greatest number of compressed teeth in jaws, and the young having a single irregular row of vomerine teeth instead of the usual triangular patch of teeth. C. myriaster follows by having numerous whitish spots around the surface sensory pits and pores on head and body, the shape of the preorbital bone different, and the preorbital bone with the least amount of ossification among the species of Conger.

Doubtful species: The proportions and counts made on the holotype of Congrus [Conger] leucophaeus Richardson (1844-1848, p. 108) that Dr. N. B. Marshall of the British Museum kindly sent to me are similar to those of Conger oceanicus and C.myriaster, which are found, respectively, along the Atlantic coast of the United States and the coast of Japan. The original description of leucophaeus lacks the type locality but Richardson (1844-1848, p. vi) lists the locality as Bahamas. The data that Dr. Marshall sent do not agree with the proportions and counts made on triporiceps, the only species so far recorded from the Bahamas. C. leucophaeus has only one supratemporal pore whereas $C$. triporiceps has three; at $476 \mathrm{~mm}$. in total length leucophaeus lacks a single irregular row of vomerine teeth whereas triporiceps has one row at that size. Therefore, without further examination of the holotype, I am unable to place the species leucophaeus.

The counts and measurements of the holotype of leucophaeus sent by Dr. Marshall are as follows: total length $476 \mathrm{~mm}$., head length 73, snout to origin of dorsal fin 92 , snout length 17 , diameter of eye 11, pectoral fin length 25 , teeth in jaws in two rows, vomerine teeth not in single row, origin of pectoral fin to origin of dorsal fin 21, pores in lateral line 41, supratemporal pore 1, and pectoral rays 18 .

Geographical distribution: The genus Conger is found in tropical and subtropical marine waters throughout the world except in the eastern Pacific along the American coast. The distribution of any species of Conger is not as wide as was believed by some authors. Only one species, C. cinereus, has a wide distribution, but it has differentiated into two subspecies, C.cinereus cinereus from Africa eastward to the Christmas Islands in the Central Pacific and $C$. cinereus marginatus in the Hawaiian Islands (fig. 4). All of the other species have a more restricted distribution. In this paper a geographical range - as far as known or as indicated by material examined-is given under each species.

There is no actual record of capture of any species of the genus Conger from the Atlantic coast of Central America. Meek and Hildebrand (1923, p. 138) state that it doubtlessly occurs on the Atlantic coast of Panama; however they had no specimen from that area. 


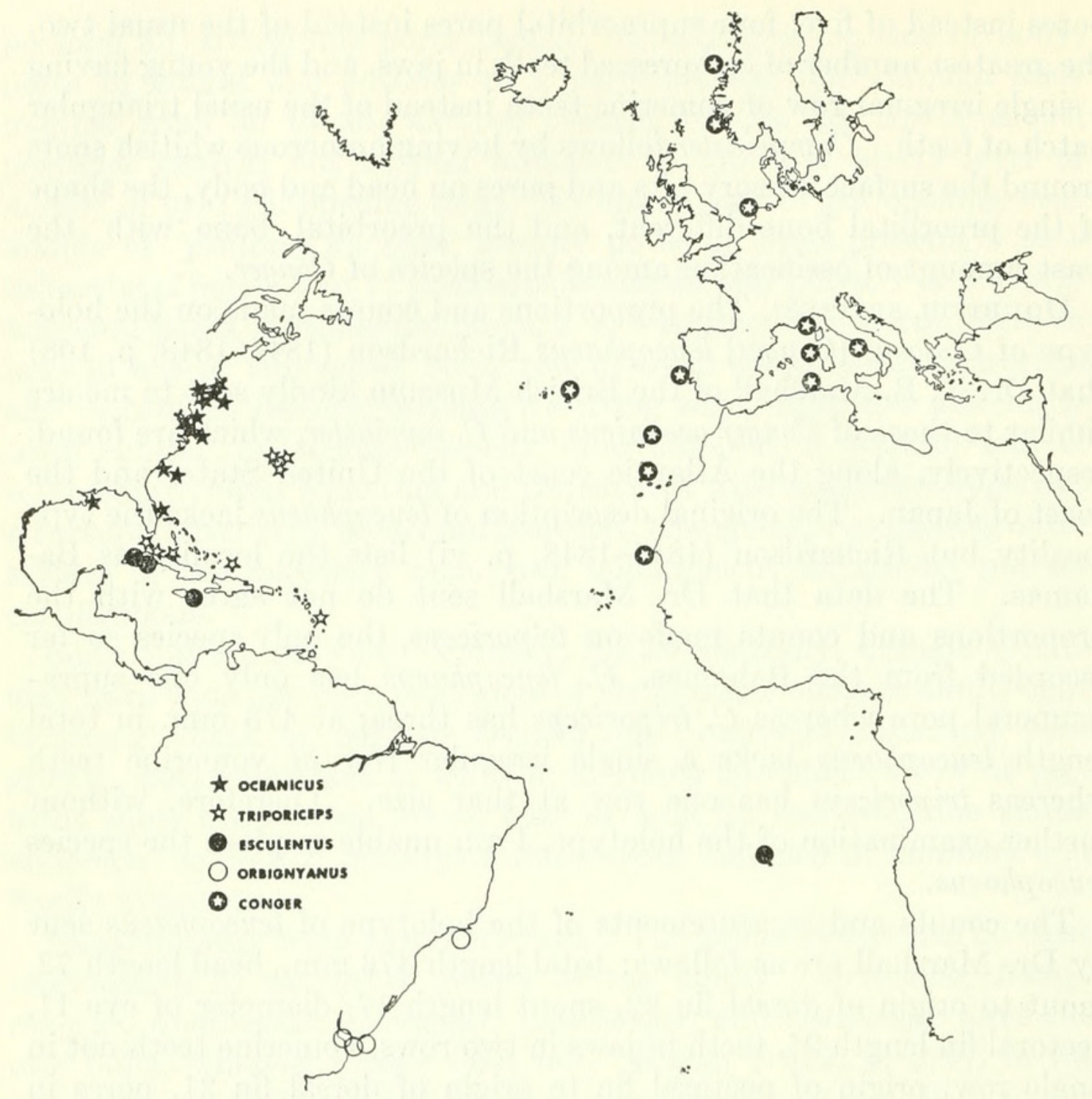

Figure 3.-Map showing distribution of the various species of Conger found in the Atlantic Ocean.

On the American coast of the Pacific Ocean, two doubtful records occur. The first such doubtful record, by Jordan and Gilbert (1882, p. 378), is of a specimen (USNM 30930) $6 \frac{1}{2}$ inches in length recorded as Leptocephalus conger from Cape San Lucas, Lower California, collected by L. Gelding. Jordan and Davis (1892, p. 665) reidentified this specimen as Ophiosoma balericum, and Ogilby (1898, p. 288) made it one of the types of the new species Congrellus gilberti. The second doubtful record of a species of Conger occurring on the American coast of the Pacific Ocean was made by Fowler $(1912$, p. 9). He described a new species, Leptocephalus caudalis (ANSP 1055), from off Lower California, collected by Dr. W. H. Jones with no date. He placed it in a new subgenus, Microconger. I examined the holotype and found it to be Conger cinereus. I cast doubt on the validity of the above 


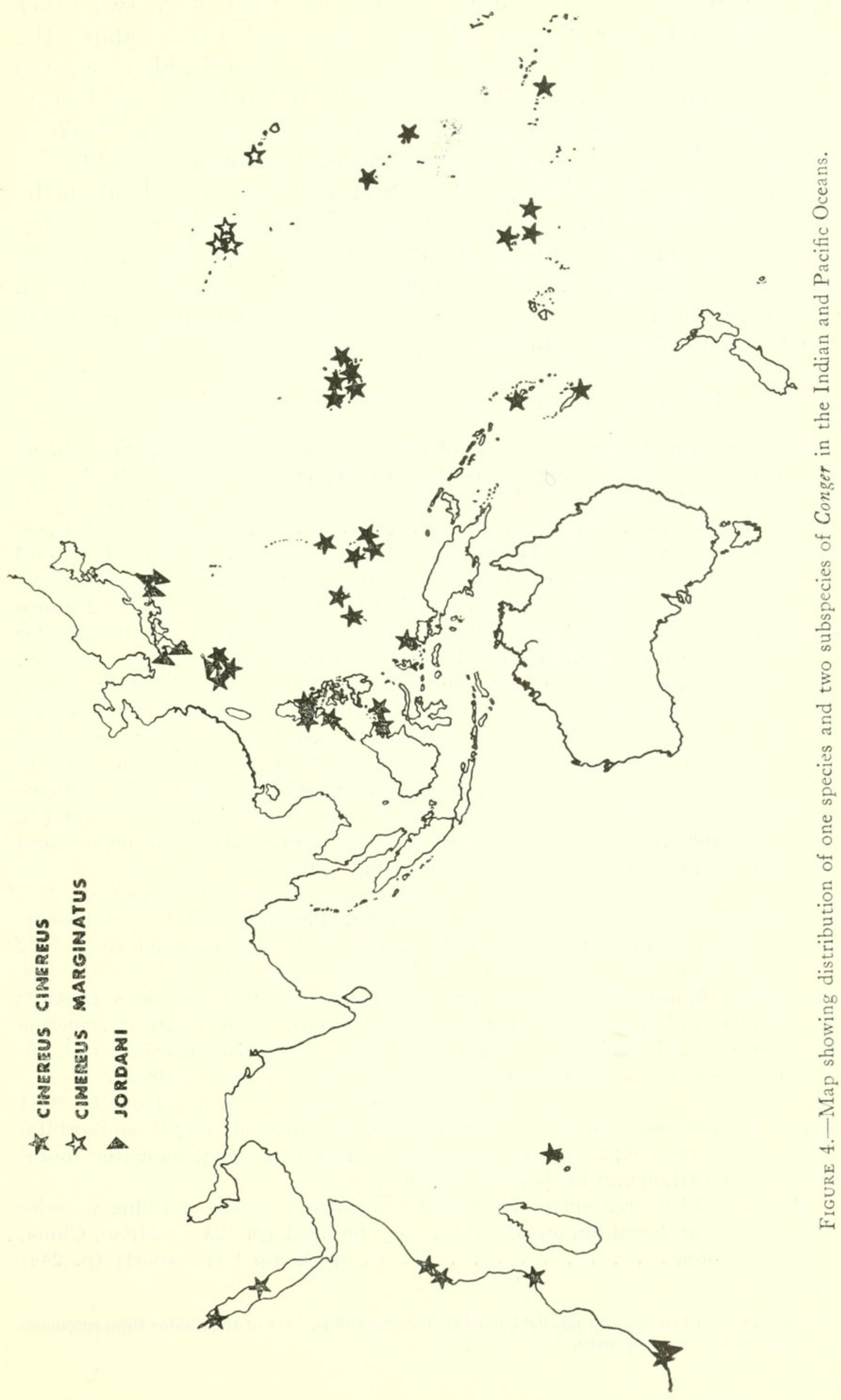


type locality because in the same collection there were two other specimens of Conger cinereus (ANSP 15326 and 15327) about the same length as the holotype of Leptocephalus caudalis, also collected by W. H. Jones and with no date, but collected at Christmas Island. These two specimens were listed by Fowler (1912, p. 9) as Leptocephalus marginatus. In the catalog entry, locality was given as "Christiana Isla, west coast of Mexico." I find no Christiana Island on the west coast of Mexico. The holotype of Leptocephalus caudalis may have come from the same lot as the other two specimens. Unless newly collected specimens from the eastern Pacific along the American coast corroborate the presence of Conger there, one must conclude that the genus is absent in the area.

\section{Key to species and subspecies of the genus Conger}

1a. Sixth suborbital pore above level of rictus of jaw ("c" of fig. 1, A); a black diagonal streak below eye generally present; one to three pores behind eye in a vertical row; sometimes wide vertical light brown bars present on body (pl. 2, B) . . . . . . . . . . . . . . . C. cinereus Rüppell

2a. Pectoral rays modally 17 (range 15 to 19 , mean 17.03); pores in lateral line modally 39 (range 36 to 41 , mean 38.39 ); pectoral rays plus lateral line pores (range 54 to 58, mean 55.94); vertebrae 139 to 146 ; distance between the upper postorbital pore to edge of eye is generally greater than distance between the lower pore to edge of eye; black spot on pectoral when present generally distinct. Indo-Pacific, Africa, Red Sea.

C. cinereus cinereus Rüppel (p. 234)

2b. Pectoral rays modally 19 (range 17 to 21 , mean 18.52); pores in lateral line modally 40 (range 39 to 42 , mean 40.23 ; pectoral rays plus pores in lateral line (range 56 to 61 , mean 58.75 ); vertebrae 148 to 152 ; distance between the upper postorbital pore to edge of eye is generally equal in distance between the lower pore to edge of eye; black spot on pectoral when present is generally more diffused. Hawaii.

C. cinereus marginatus Valenciennes (p. 232)

1b. Sixth suborbital pore in line with rictus of jaw; black streak below eye absent; no pores behind eye in a vertical row (except triporiceps which has 1 or 2 postorbital pores); wide barring on body never present.

3a. Three supratemporal pores present; 1 or 2 postorbital pores present; 4 supraorbital pores present; premaxillary tooth-patch squarish; vomerine teeth in a single irregular row in small to medium sized specimens and in large ones a triangular patch. Bermuda, Bahamas, Cuba, Brazil.

C. triporiceps, new name (p. 243)

3b. One supratemporal pore present; postorbital pore absent; 2 supraorbital pores present; maxillary tooth-patch wider than long; vomerine toothpatch triangular in shape at all sizes.

4a. A whitish area surrounds sensory pores and organs, forming a series below dorsal fin, on lateral line, and on head (pl. 3,A). Japan, China, Korea . . . . . . . . . . . . C. myriaster ${ }^{1}$ (Brevoort) (p. 244)

\footnotetext{
${ }^{1}$ In some preserved specimens these light spots are not discernible. For distinguishing these specimens see remarks under Conger myriaster.
} 
4b. Whitish spots as above not present.

5a. Pores in lateral line more than 43 (except oceanicus, which has 39 to 44).

6a. Diameter of eye less than 1.75 percent of total length (2 to 3 into snout), pectoral fin rays 15 to 17 , origin of dorsal fin one-fifth of pectoral fin or more behind posterior tip of pectoral fin. Atlantic South America . . . . . C. orbignyanus Valenciennes (p. 247)

6b. Diameter of eye more than 1.75 percent of total length (1.36 to 2.11 into snout), pectoral rays 17 to 20 , origin of pectoral fin two-fifths of pectoral fin length behind posterior tip of pectoral fin tip anteriorly. European waters . . C. conger (Linnaeus) (p. 248)

5 b. Pores in lateral line fewer than 44.

7a. Teeth in maxillary generally in one row, sometimes 3 or 4 in inner row; in small specimens mandibular teeth in one row, some may have 3 to 6 teeth in inner row.

8a. Length of head 125 to 148 ; diameter of eye less than 2.50 percent of total length (or eye into snout 1.46 to 1.99 times); pores in lateral line modally 38, range 36 to 40 ; vertebrae 141 to 144 . Japan, Africa . . . . . C. jordani, new species (p. 250)

8 b. Length of head 141 to 157 ; diameter of eye more than 2.25 percent of total length (or eye into snout 1.21 to 1.42 times); pores in lateral line modally 36, range 35 to 36 ; vertebrae 137 to 139 . Hawaii . . . . . . . C. oligoporus, new species (p. 251)

7b. Teeth in maxillary generally in two rows; in small specimens maxillary may have 1 row but the mandibular teeth in 2 rows.

9a. Pores in lateral line fewer than 37.

10a. Pectoral rays 18 to 19 ; compressed teeth in upper jaw fewer in number, see table 4 . West Indies

C. esculentus Poey (p. 253)

10b. Pectoral rays 17 ; compressed teeth in lower jaw more numerous, see table 4. Philippines and East Indies.

C. macrocephalus, new species (p. 254)

9b. Pores in lateral line 37 or more.

11a. Pectoral rays 19 to 21 ; origin of dorsal fin anterior to a vertical line through pectoral fin tip. Japan.

C. erebennus (Jordan and Snyder) (p. 254)

11b. Pectoral rays less than 19 .

12a. Vertebrae less than 136, Philippines and East Indies.

12b. Vertebrae more than 139 .

C. philippinus, new species (p. 255)

13a. Vertebrae more than 150, diameter of eye less than 1.50 percent of total length. New Zealand, South Australia.

C. verreauxi Kaup (p. 257)

13b. Vertebrae less than 147 , diameter of eye more than 1.50 percent of total length.

14a. Origin of dorsal fin less than 50 percent of pectoral fin length behind pectoral fin tip; compressed teeth in upper jaw fewer in number (fig. 2). Western Atlantic on the United States coast.

C. oceanicus (Mitchell) (p. 258)

14b. Origin of dorsal fin more than 20 percent of pectoral fin length behind pectoral fin tip; compressed teeth in upper jaw more numerous (fig. 2). South Australia.

C. wilsoni (Block and Schneider) (p. 256) 


\section{Conger cinereus marginatus Valenciennes}

Figures 4-6

Conger marginatus Valenciennes, 1841, p. 201, pl. 9, fig. 1 (type locality, Hawaii).Kaup, 1856b, p. 114.

Leptocephalus marginatus Jordan and Evermann, 1905, p. 76.-Fowler, 1912, p. 9 (Hawaii).

Conger cinereus Fowler, 1928, p. 37 (in part).

Specimens studied: 74 specimens, from the various islands of the Hawaiian chain, $115 \mathrm{~mm}$. to $1004 \mathrm{~mm}$. in total length.

Diagnosis: Sixth infraorbital pore above rictus of jaw; 7 to 9 infraorbital pores; preoperculo-mandibular pores 10 ; supraorbital pores 2 ; preorbital bone shows the greatest amount of ossification; pectoral rays 17 to 20 ; pores in lateral line 39 to 42 ; black spot on pectoral fully developed at total length about $215 \mathrm{~mm}$., and black spot diffused; vertebrae 148 to 152 .

Description: Distance from tip of snout to origin of dorsal fin 132 to 160 , length of upper jaw (to rictus) 42 to 56, length of pectoral 29 to 49 ; supratemporal pore 1 ; infraorbital pores 7 to 9 ; preoperculomandibular pores 10 ; supraorbital pores 2 ; compressed teeth in upper jaw 30 to 62 ; in lower jaw 30 to 60 ; vertebrae $148-152$; two rows of teeth in jaws; premaxillary tooth-patch wider than long. Additional counts and proportional measurements are recorded in tables 1-3, 5,6 and in figure 5 .

The black pectoral spot begins to appear at a total length of about $115 \mathrm{~mm}$. and is fully developed at about $215 \mathrm{~mm}$. (fig. 6); the black on distal edge of anal and dorsal fins is fully developed at about $140 \mathrm{~mm}$.

Geographical range: Hawaiian Islands.

Remarks: The number of vertebrae may prove to be a good character to separate Conger cinereus cinereus and $C$. $c$. cinereus as full species; however, more counts from the various localities are needed. The two forms will be left as subspecies for the present. Vertebrae counts taken of the two forms, by localities, are as follows: Marshall Islands, Rongerik Island 139; Samoa, Tau Island 144; New Hebrides 139, 140; Guam 141; Okinawa 141, 145; Red Sea 141; South Africa 146, 146; Hawaiian Islands, Oahu, Honolulu 148, 148, 150, 151, and Waimea Bay 148, 151, 152, and Hawaii 149, 151.

In Conger cinereus marginatus the distance from the upper postorbital pore (ninth infraorbital pore) to edge of eye is usually equal to the distance from the lower postorbital pore (seventh infraorbital pore) to eye, whereas in C.c. cinereus the former distance is usually greater than that of the latter distance.

In C. c. marginatus the black spot is fully developed when the eels are about $215 \mathrm{~mm}$. long, whereas in C. c. cinereus it is not fully de- 
veloped until the eels are about 280 to $480 \mathrm{~mm}$. long. There is population divergence in this development in C.c. cinereus from the various geographical localities (fig. 6). Specimens from the Marshall Islands show the full development at a length of about $480 \mathrm{~mm}$., whereas those from Okinawa show full development at about $280 \mathrm{~mm}$.
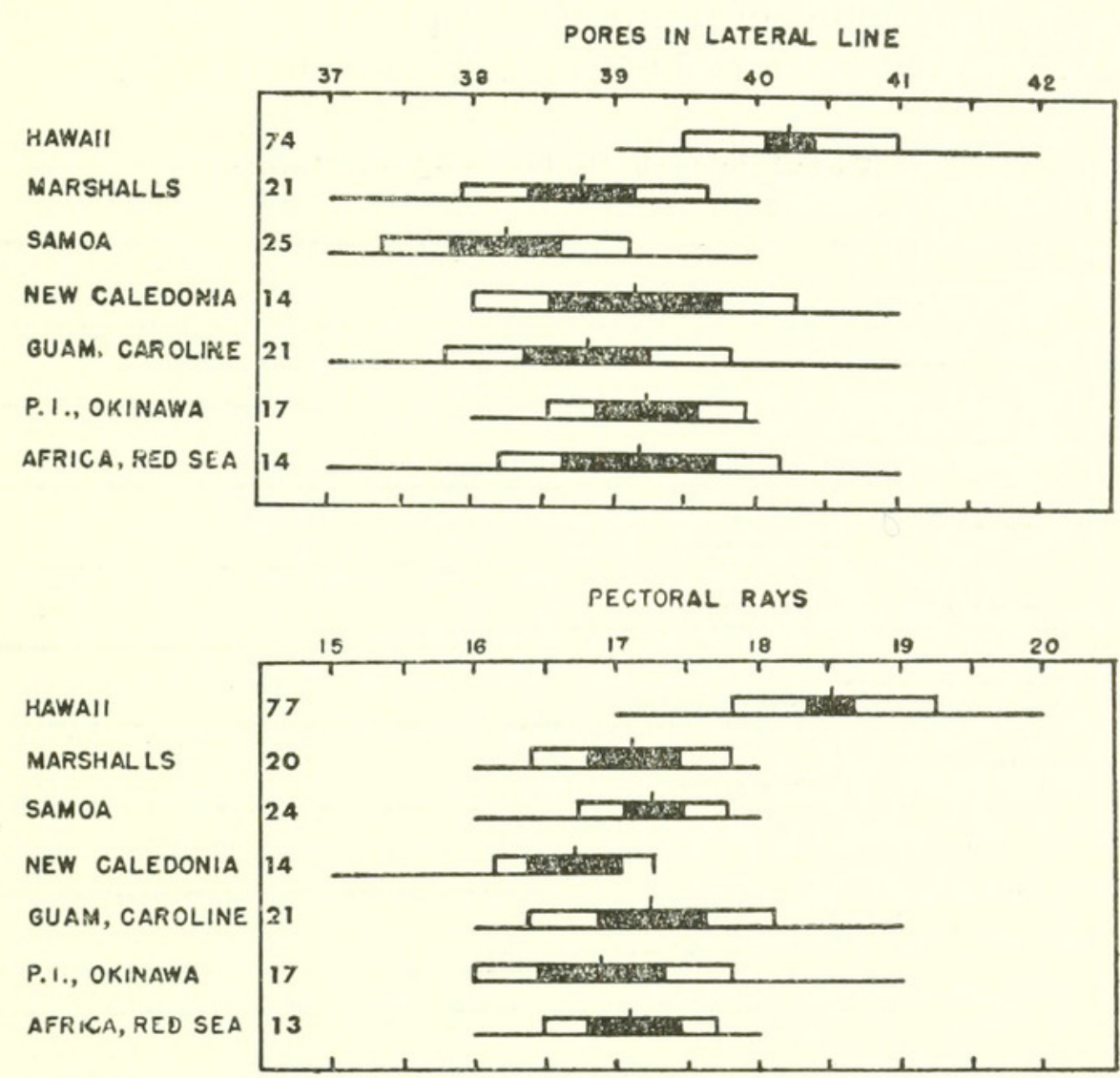

PORES IN LATERAL LINE PLUS PECTORAL RAYS

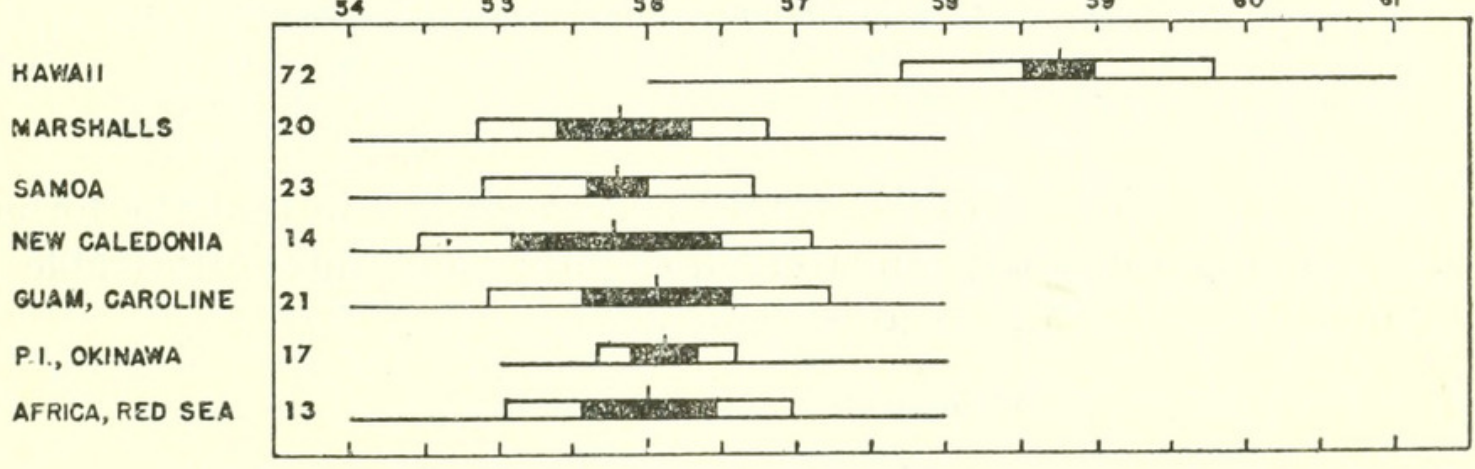

Figure 5.-Pores and pectoral rays in the subspecies Conger cinereus cinereus and $C$. $c$. marginatus from the various geographical areas. All specimens found in Hawaii are of C. c. marginatus, while all the specimens found in the other areas are of C. c. cinereus. Numbers at the left indicate the number of specimens examined from each area. In each horizontal bar-graph the range of variation is represented by the solid bottom line; the mean is represented by the small vertical line at the tip; twice the standard error on either side of the mean is represented by half the solid rectangle; and one standard deviation on either side of the mean is represented by the hollow rectangle plus half the solid rectangle. 
There may be a correlation between this development and the temperature of the water, since specimens in colder waters develop this spot at a shorter length than those found in warmer waters.

The mean for the number of pectoral rays is 18.52 in C.c. marginatus and 17.03 in C.c.cinereus; the mean for the number of pores in lateral line is 40.23 in C. c. marginatus and 38.39 in C.c. cinereus; and the mean for the character index of pectoral rays plus pores in lateral line is 58.75 in C. c. marginatus and 55.94 in C. c. cinereus (fig. 5).

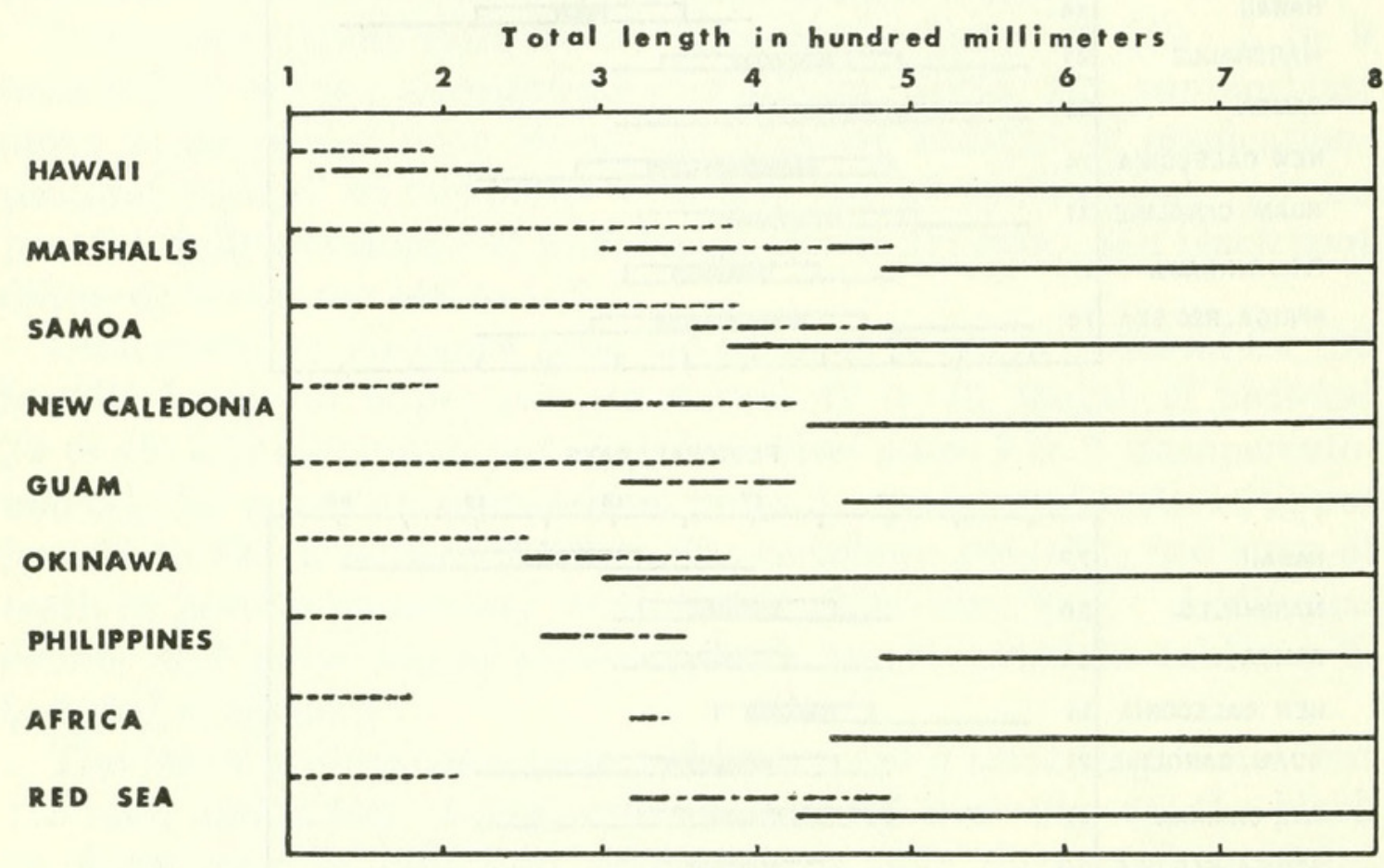

Figure 6.-The relationship of body length with development of black spot on the pectoral fin in Conger cinereus cinereus and C. c. marginatus, by locality. All specimens found in Hawaii are of the subspecies $C$. c. marginatus, while all the specimens found in the other areas are of the subspecies $C$. c. cinereus. Lines indicated by short dashes represent pectoral fins all pale; those indicated by short dashes and long dashes represent pectoral fins with traces of black. The solid line represents the black spot fully developed.

Also, C. c. cinereus differs from C. c. marginatus in that the former has the origin of dorsal fin situated slightly more anteriorly (table 1) and the length of the head is slightly shorter (fig. 5).

\section{Conger cinereus cinereus Rüppell}

Figures 4-6; Plate 2

Conger cinereus Rüppell, 1828, p. 115 (type locality, Red Sea).-Klunzinger, 1871 , p. 607 .-Weber, 1913 , p. 43 .-Weber and de Beaufort, 1916 , p. 258.Jordan and Hubbs, 1925, p. 193.-Barnard, 1925, p. 187 (Natal coast).Schultz, 1943, p. 44 (Phoenix and Samoan Islands).-Aoyagi, 1943, p. 5, fig. 1.-J. L. B. Smith, 1949, p. 393, pl. 99, fig. 1111.

Conger altipinnis Kaup, 1856a, p. 72 (type locality, Isle of Bourbon).-Kaup, 1856b, p. 114.-Playfair and Günther, 1866, p. 125. 
Conger noordzieki Bleeker, 1857, p. 86 (type locality, Ambon); 1864, p. 26, pl. 167,

figs. 2, 3.-Schultz and Collaborators, 1953, p. 83 (Marshall Islands).

Leptocephalus riukiuanus Jordan and Snyder, 1901, p. 852, fig. 4 (type locality,

Riu Kiu Islands).

Leptocephalus caudalus Fowler, 1912, p. 9 (type locality, coast of California?). Leptocephalus marginatus Fowler, 1912, p. 9 (Christmas Island).

Conger marginatus Günther, 1870, p. 38.

Leptocephalus cinereus Herre, 1934, p. 16 (Philippines: Manila, Culion, Jolo).

Forskalichthys cinereus Whitley, 1935, p. 219.-Fowler, 1944b, p. 187 (New Hebrides).

Specimens studied: 112 specimens, from $90 \mathrm{~mm}$. to $923 \mathrm{~mm}$. in total length, from the Marshalls, Phoenix, Guam, Okinawa, Philippines, Africa, and the Red Sea.

Diagnosis: Vertebrae 139 to 146; sixth infraorbital pore above rictus of jaw; infraorbital pores 7 to 9 ; preoperculo-mandibular pores 10 ; supraorbital pores 2 ; preorbital bone show the greatest amount of ossification; pectoral rays 15 to 19 ; pores in lateral line 37 to 41 ; black spot on pectoral fin more distinct and fully developed at total length of about $280 \mathrm{~mm}$. to $480 \mathrm{~mm}$.

Description: Distance from tip of snout to origin of dorsal fin 127 to 156 ; length of upper jaw (to rictus) 34 to 51 ; length of pectoral fin 29 to 42 ; supratemporal pore 1 ; infraorbital pores 7 to 9 ; preoperculomandibular pores 10 ; supraorbital pores 2 ; compressed teeth in upper jaw 32 to 76 ; in lower jaw 31 to 72 ; vertebrae 139 to 146 ; two rows of teeth in jaws laterally; premaxillary tooth-patch wider than long. Bleeker (1864, p. 26) states anal rays 258 to 280 , dorsal rays 288 to 296. Additional counts and proportional measurements are recorded in tables $1-3,5,6$, and figure 3 .

Dr. J. Randall (in litt.), who has observed the subspecies in the field, believes it to be nocturnal. He states that at night it displays the barred color pattern, broad dark gray bands showing on lighter gray ground color.

Geographical range: Marshall, Phoenix, and Christmas Islands, Palmyra, New Caledonia, Guam, Okinawa, Japan, Philippines, westward throughout the Indian Ocean, Red Sea, east coast of Africa, and South Africa. Whitley (1935, p. 219) mentions specimens from North Queensland, Australia.

Remarks: For differences between Conger cinereus marginatus and C. c. cinereus see remarks under marginatus. Dr. J. Böhlke examined the type of Leptocephalus riukiuanus Jordan and Snyder (SNHM 6468 ) and informed me that the sixth infraorbital pore is above the rictus of jaw instead of behind it and that the black diagonal streak is present beneath the eye. These characteristics place this species in the synonomy of C.c. cinereus.

$463736-58-3$ 


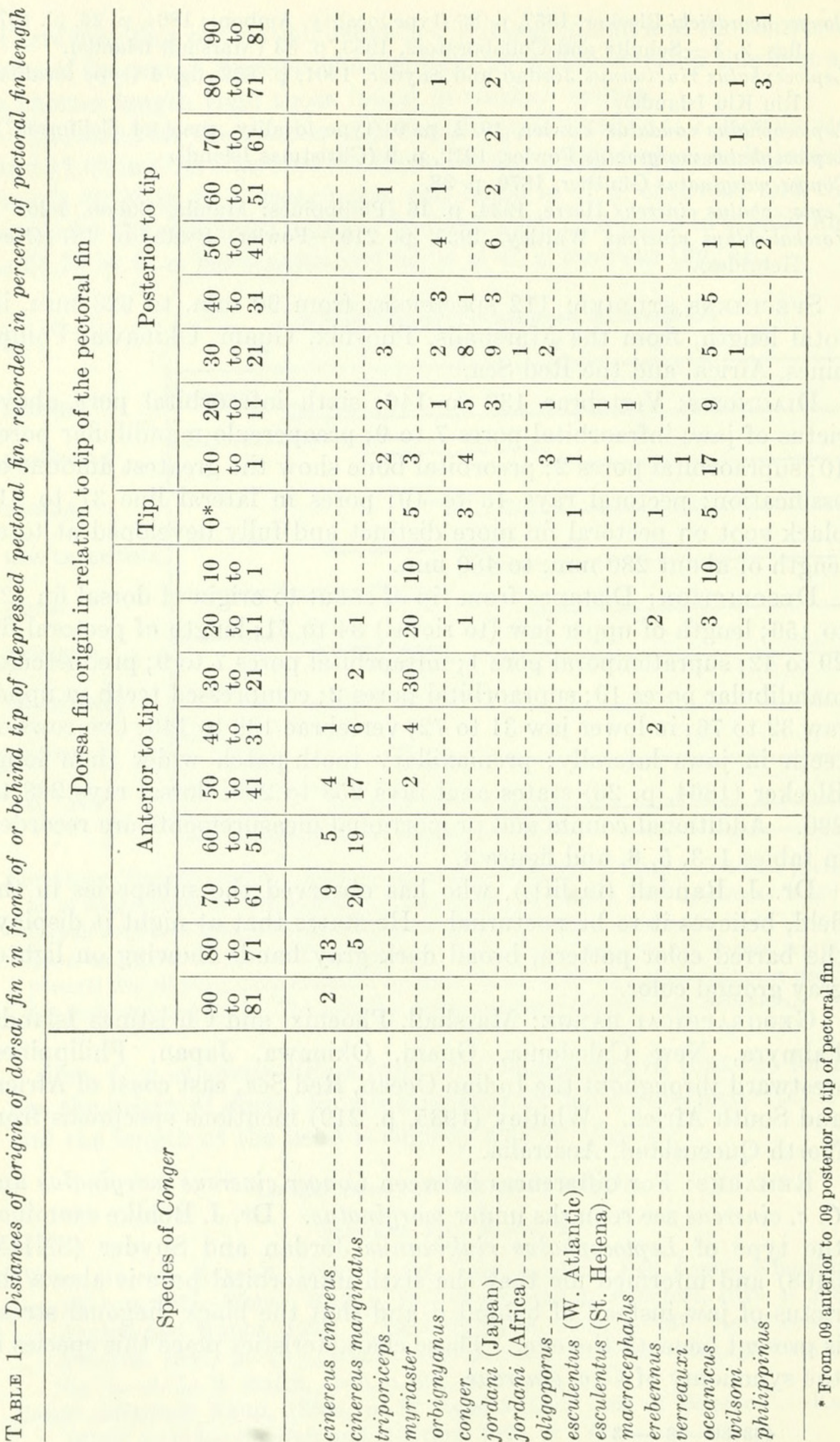




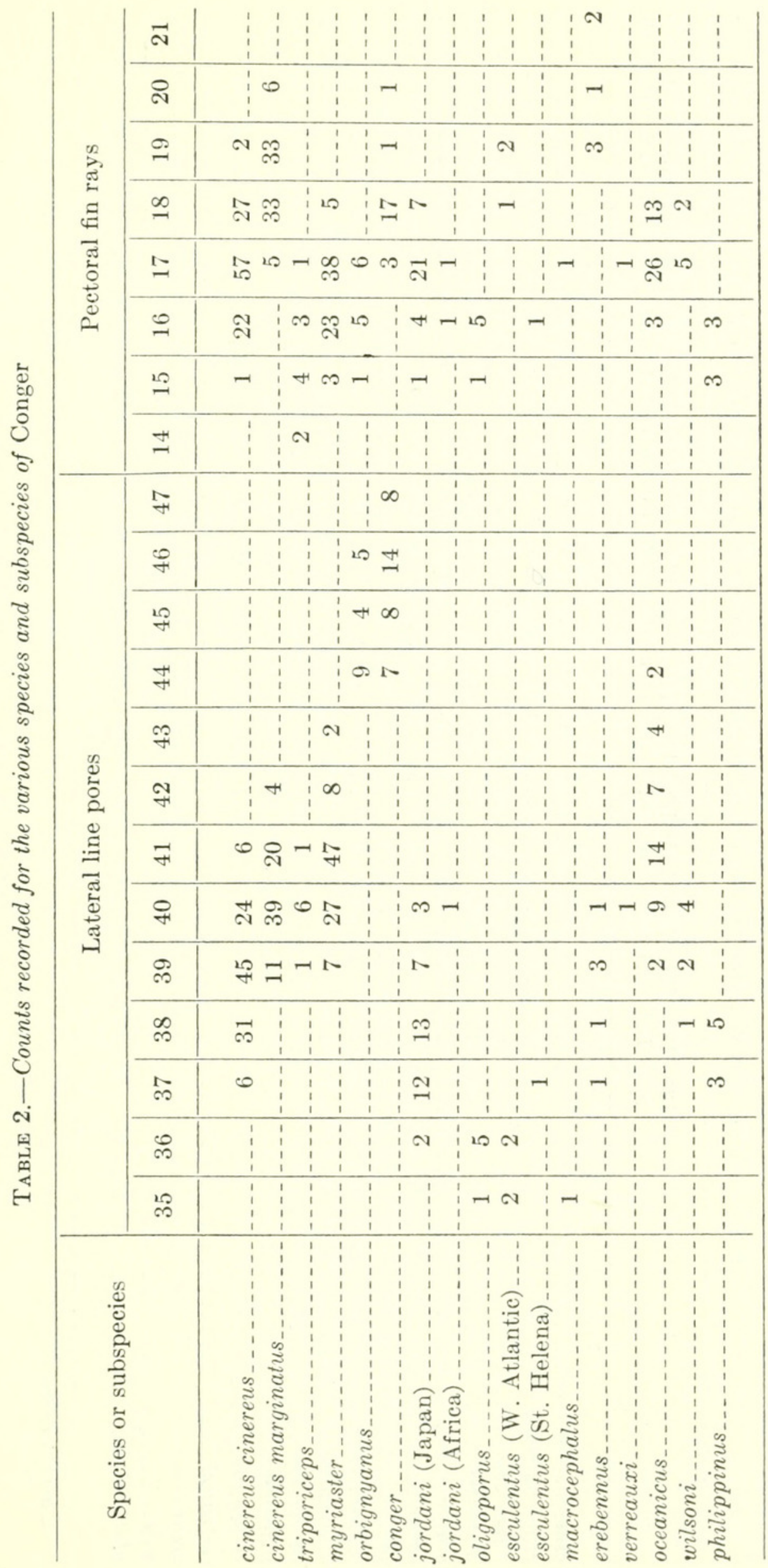




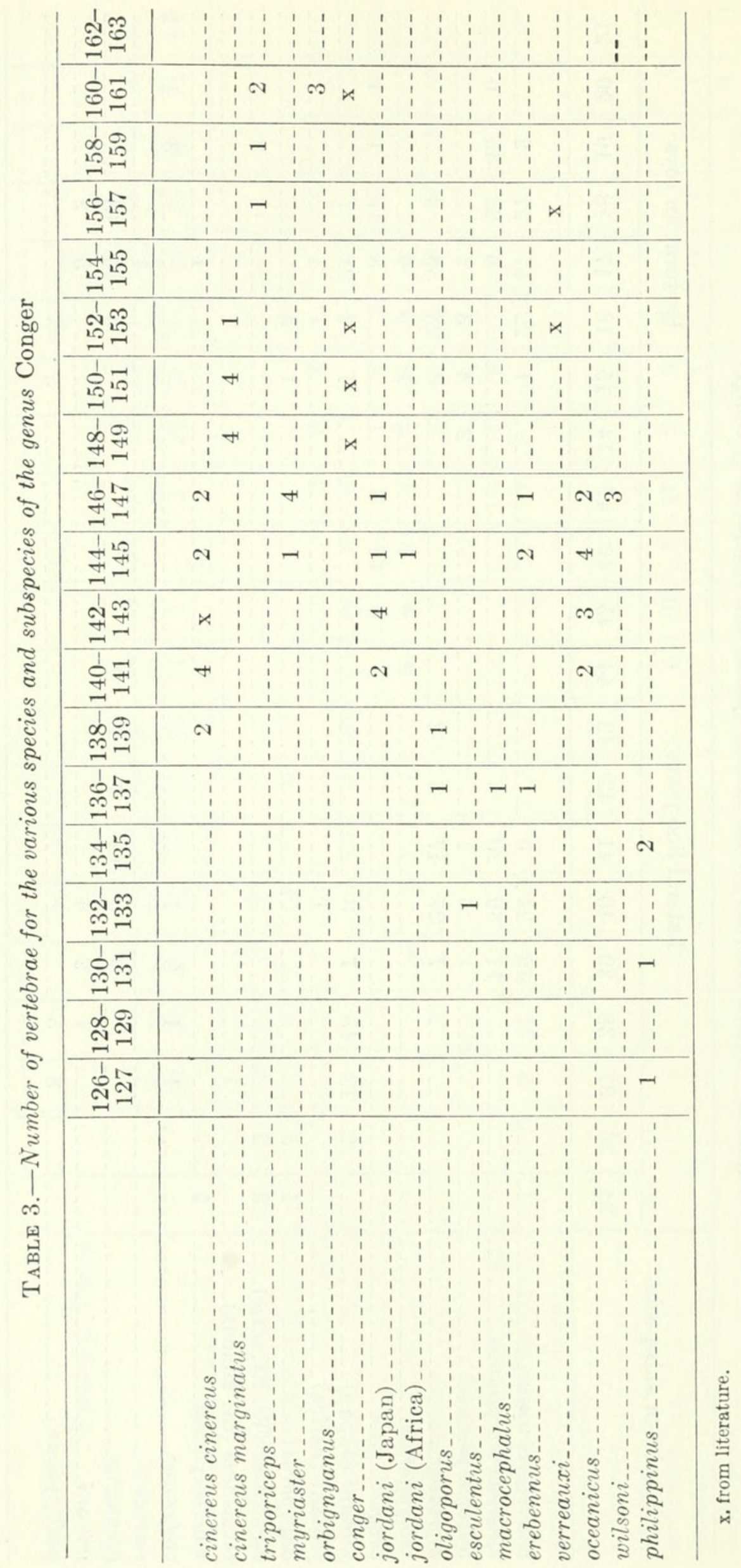




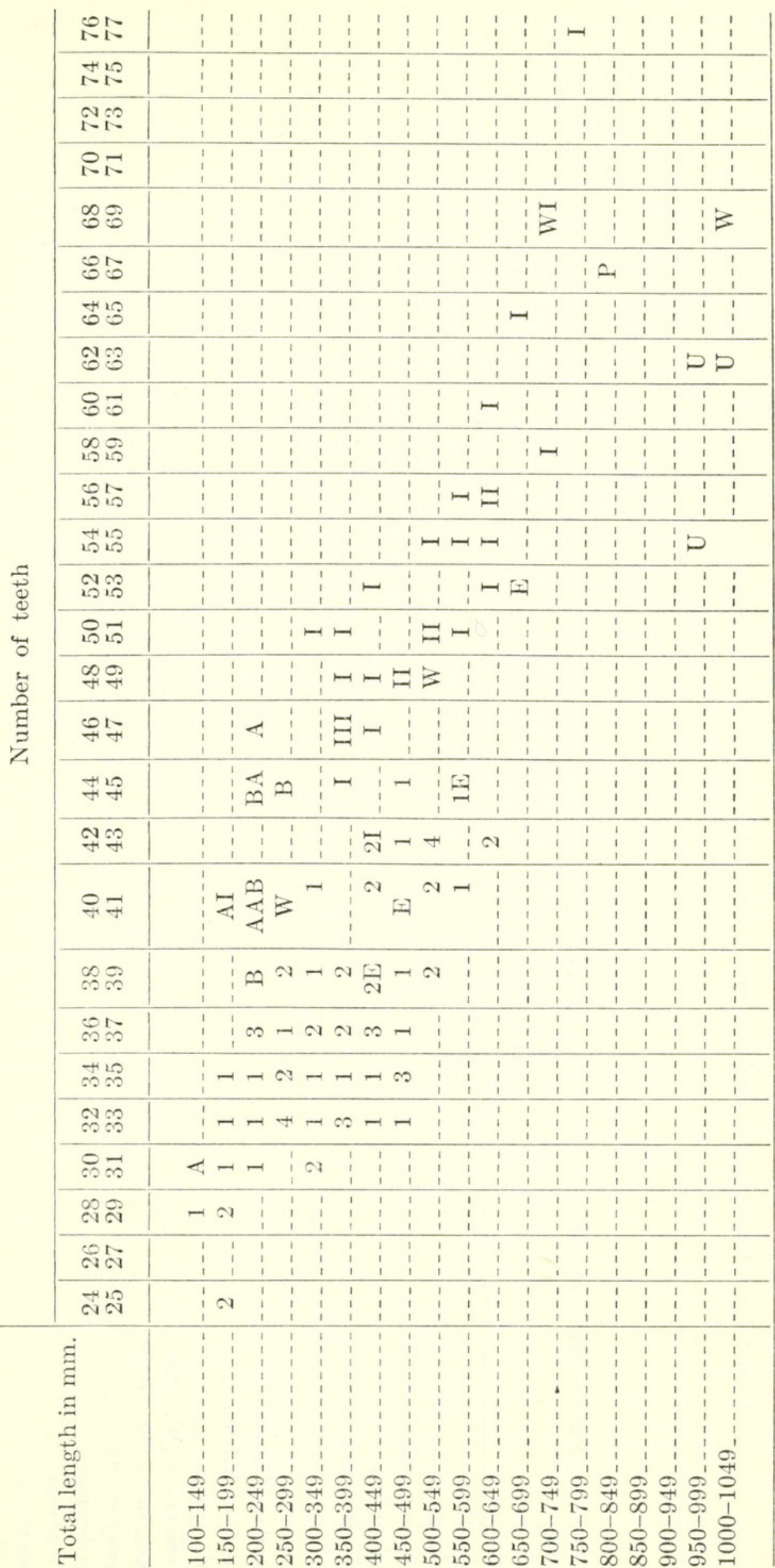




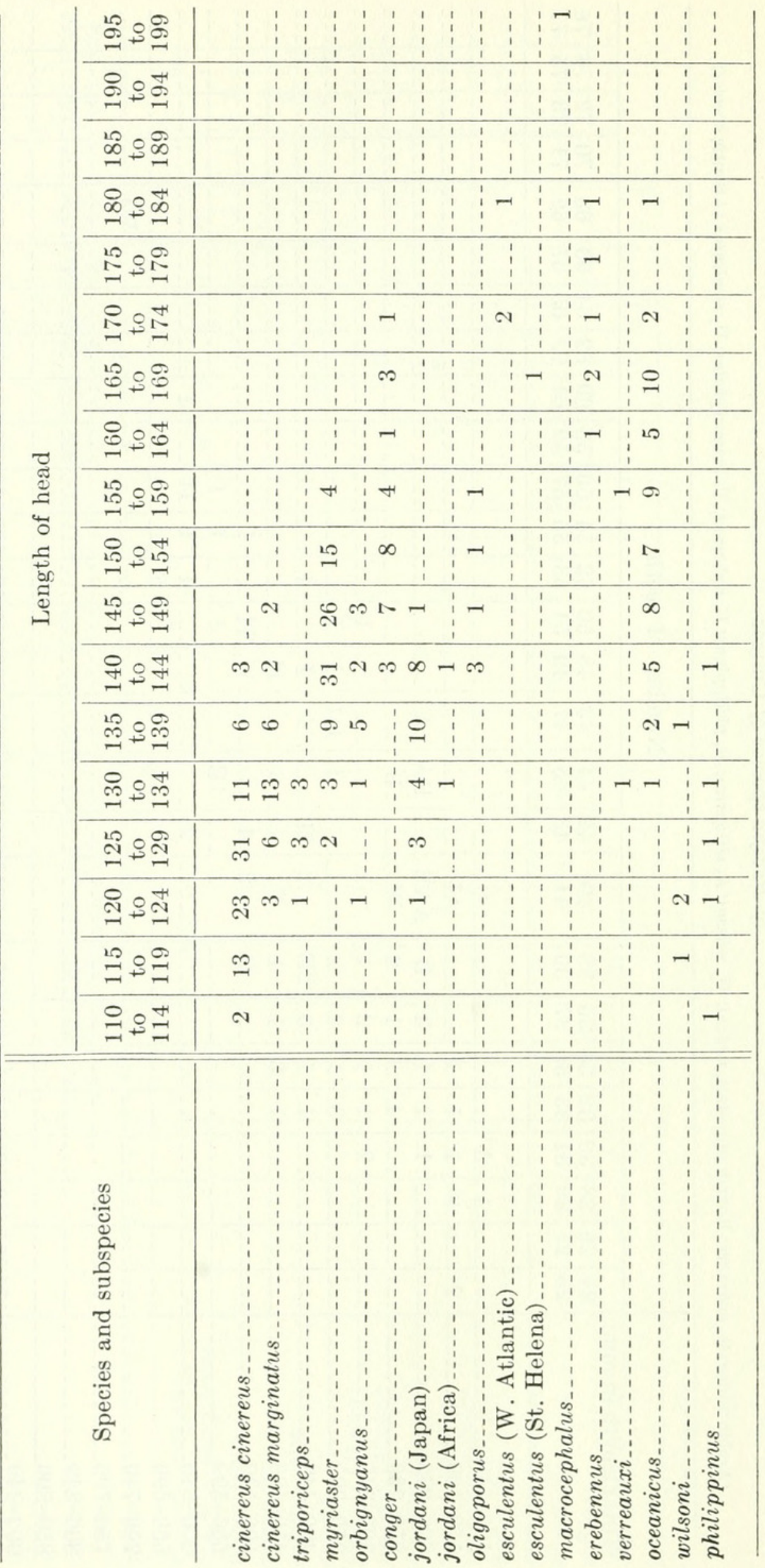




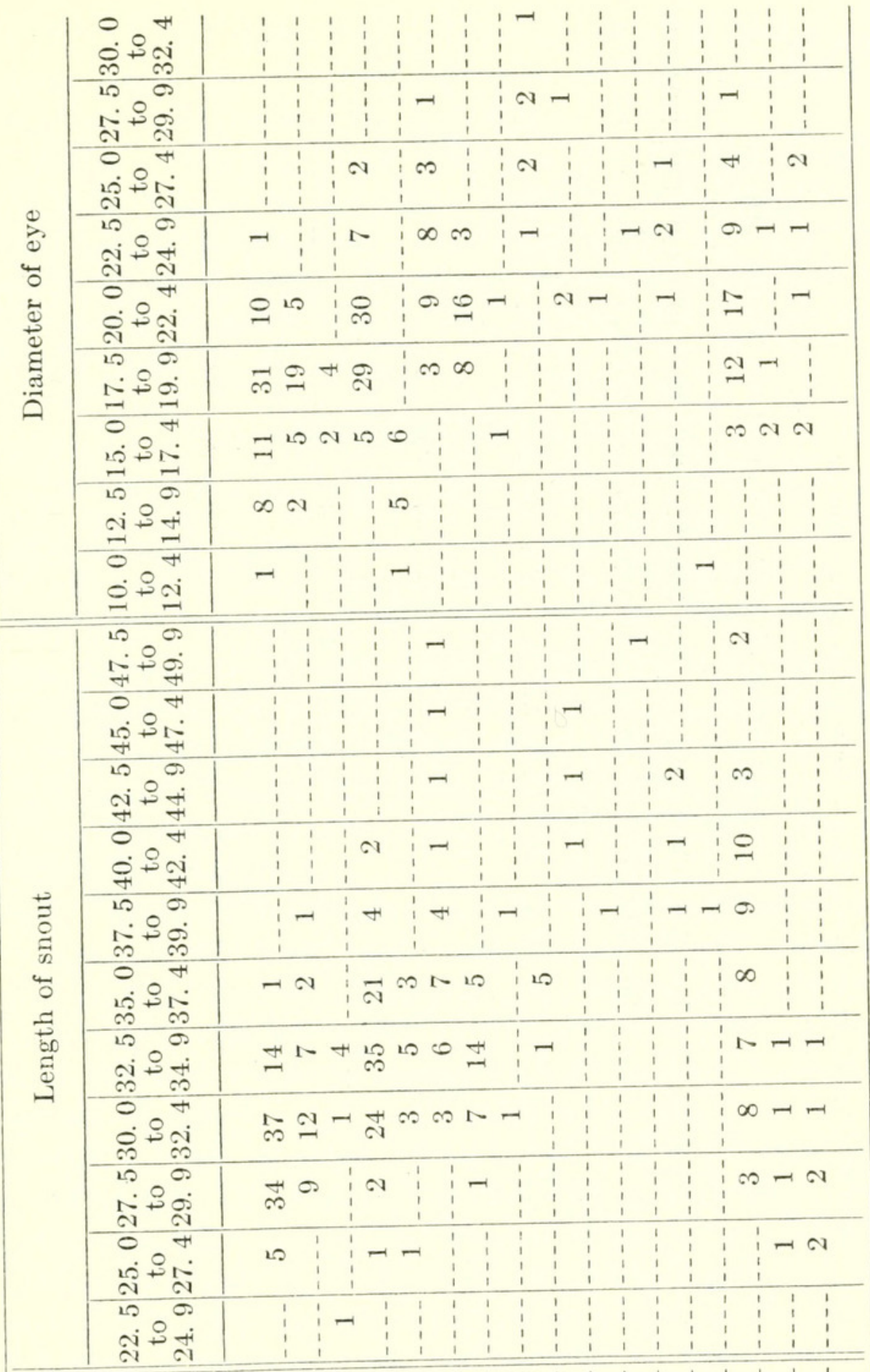

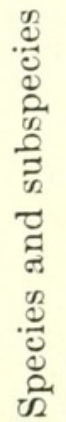

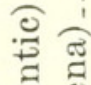

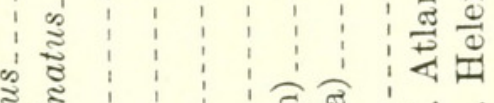

密导:

:

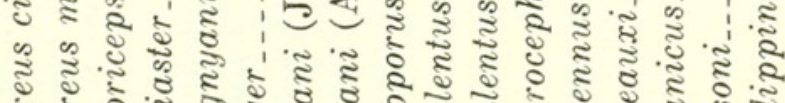

\%

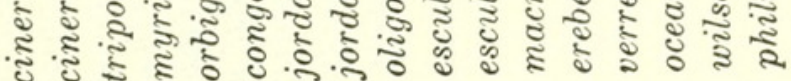




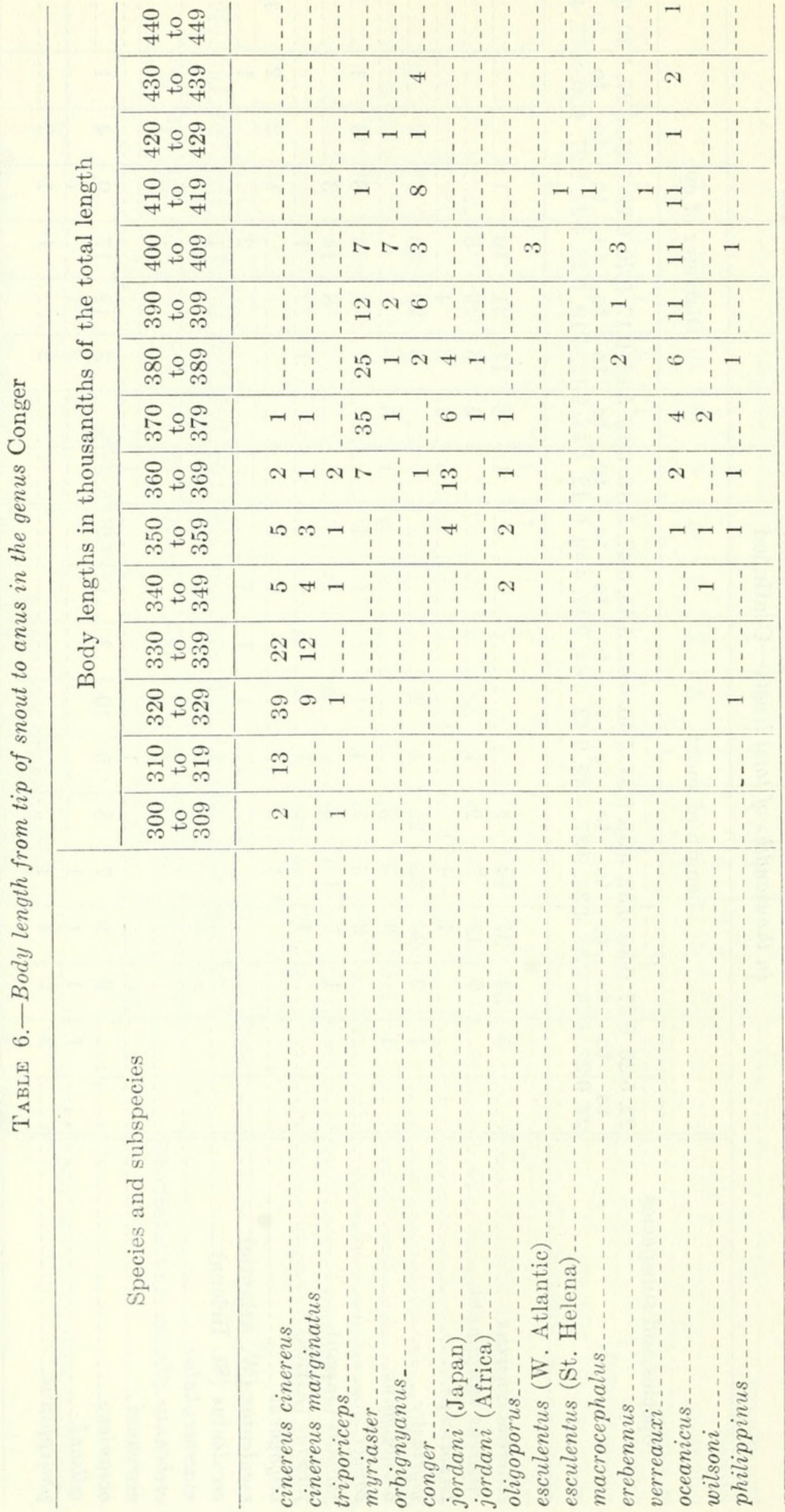


Fowler (1912, p. 9) described as new the species Leptocephalus caudalus, from the coast of California. I doubt the validity of this record and discuss this problem on page 228 .

Dr. E. A. Lachner has examined Rüppell's type of Conger cinereus (No. 766, total length about $338 \mathrm{~mm}$.) deposited in the Senckenberg Museum at Frankfort, Germany. He noted that the sixth infraorbital pore is above rictus of jaw, that the lateral line pores from anus forward are 39 in number, and that there may have been a dark streak under the eye.

\section{Conger triporiceps, new name}

Figures 2, 3; Plates 1,D, 4,A

Conger brasiliensis, Kaup, 1856b, p. 115 (type locality, Brazil).

Conger occidentalis (not De Kay) Kaup, 1856b, p. 114 (Martinique).

Leptocephalus conger Nichols, 1921, p. 22; Fowler, 1944a, p. 436 (in part).

Specimens studied: Eight specimens, ranging in total length from 622 to $950 \mathrm{~mm}$., from the following localities: Brazil, holotype (PM 8427 ) of Kaup's C. brasiliensis (examined by Dr. E. A. Lachner at Museum National d'Histoire Naturelle, Paris); Cuba (USNM 24936, 9792, 19799); Bahamas, Turks Island (AMNH 7240); Bermuda (CNHM 48606, 48339, 48945).

Diagnosis: Three supratemporal pores; 11 preoperculo-mandibular pores; four supraorbital pores; greater number of compressed teeth in jaws than in other species (fig. 2); in young specimens vomerine teeth in a single irregular row; premaxillary tooth-patch squarish; ossification developed across sensory canal of preorbital bone, one or two post orbital pores.

Description: Length of head 126 to 132 ; tip of snout to origin of dorsal fin 164 to 177 ; tip of snout to anus 301 to 366 ; snout length 24 to 35 ; diameter of eye 17 to 19 ; length of upper jaw (to rictus) 44 to 51 ; length of pectoral fins 36 to 42 ; pectoral fin rays 14 to 17 ; pores in lateral line 39 to 41 ; teeth in jaws in a single row, at times with a few scattered teeth on inner row; number of compressed teeth in upper jaw 72 to 90 ; in lower jaw 74 to 97 ; vomerine teeth in single irregular row, in large specimens in a traingular patch; premaxillary tooth-patch squarish, with 40 to 105 teeth; preoperculo-mandibular pores 11; supratemporal pores 3 ; supraorbital pores 4, infraorbital pores 7 or 8 ; vertebrae 157 to 160 ; origin of dorsal fin 4.3 percent anterior to pectoral tip to 28.35 percent posterior to pectoral tip; ossification developed across sensory canal of preorbital bone (see pl. 1,D); pectoral fins colored black with lower one-third of fin pale. Measurements and counts are recorded in tables 1 to $3,5,6$ and in figure 2. 
Geographical range: Brazil, Bermuda, Bahamas, Cuba, Martinique, and Pensacola, Fla.

Remarks: Ranzani (1840, p. 79, pl. 13, figs. 1,a,b) described a new species, Conger brasiliensis; however his species belongs with the muraenesocid eels. Kaup (1856a) described a new conger as Conger brasiliensis, which makes this name a junior primary homonym. According to Article 36 of the International Rules of Zoological Nomenclature, a rejected homonym can never be used again; therefore, I give Kaup's $C$. brasiliensis, a new name, $C$. triporiceps. This name refers to the three supratemporal pores on the head, which is a distinguishing character of this species.

Kaup's (1856b, p. 114) description of C. occidentalis states vomerine teeth 9, small and irregularly spaced. The only species that has such a few number of vomerine teeth is triporiceps; also, it has the greatest number of compressed teeth (fig. 2).

The head of one specimen (USNM 30710) was obtained from Pensacola, Fla. It was identified as this species by the ossification bridging across the sensory canal of the preorbital bone and the numerous compressed teeth in the jaws. This is the only species in the Atlantic that has the preorbital bone with ossification bridging across the sensory canal.

\section{Conger myriaster (Brevoort)}

Figure 7; Plates 1,A, 3,A

Anguilla myriaster Brevoort, 1856, p. 282, pl. 11, fig. 2 (type locality, Hakodate, Japan).

Congromuraena myriaster Günther, 1870, p. 40, footnote.

Ophiosoma? myriaster Bleeker, 1879, p. 26.

Conger japonica Bleeker, 1879, p. 32, pl. 2, fig. 2.

Conger myriaster Steindachner, 1896, p. 222, pl. 4, fig. 2.

Leptocephalus myriaster Jordan and Snyder, 1901, p. 849.-Tanaka, 1911, pl. 19, figs. 69,70 ; pl. 20 , fig. 77 ; 1912, p. 78 .-Fowler, 1912, p. 9.

Astroconger myriaster Jordan and Hubbs, 1925, p. 194.-Mori, 1952, p. 64.Matsubara, 1955, p. 337.

[?]Leptocephalus kiiensis Ui, 1931 (not seen).

Specimens studied: 152 specimens from 129 to $606 \mathrm{~mm}$. in total length from the following localities: JAPAN: Mororan, SNHM 6798 (5 specimens); Hakodate USNM 48194, 49898, 71027, 163410 (4); Aomori Ken, Pacific coast UMMZ 165496, 165505; Sendai, Shiogama USNM 71823 (2), UMMZ 165512 (2); coast of Boshyu, Chiba Ken UMMZ 165528; Tokyo Bay UMMZ 165515 (3); Tokyo market, USNM 49977 (3), 38806 (2), 71870, 151844 (2), SNHM 6696 (21); Yokohama market, SNHM 30624 (41), 26779, USNM 151793; Sagami Sea, Shimoda USNM 57596; Misaki, USNM 71868, MCZ 29018 (2); Suruga Bay UMMZ 177297, USNM 163411, 163412; 

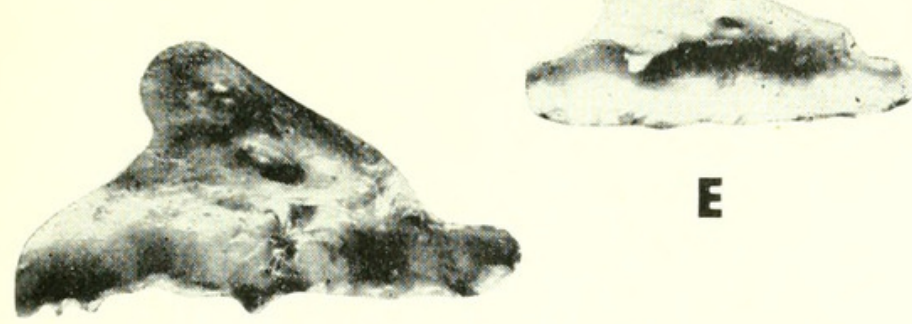

$\mathbf{E}$
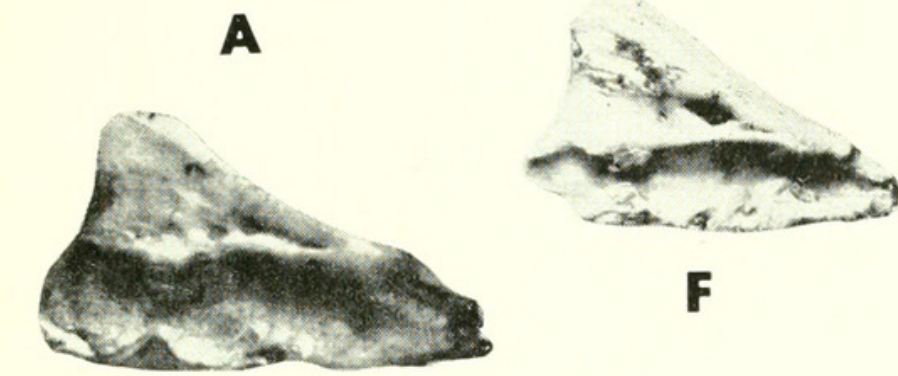

$\mathbf{F}$
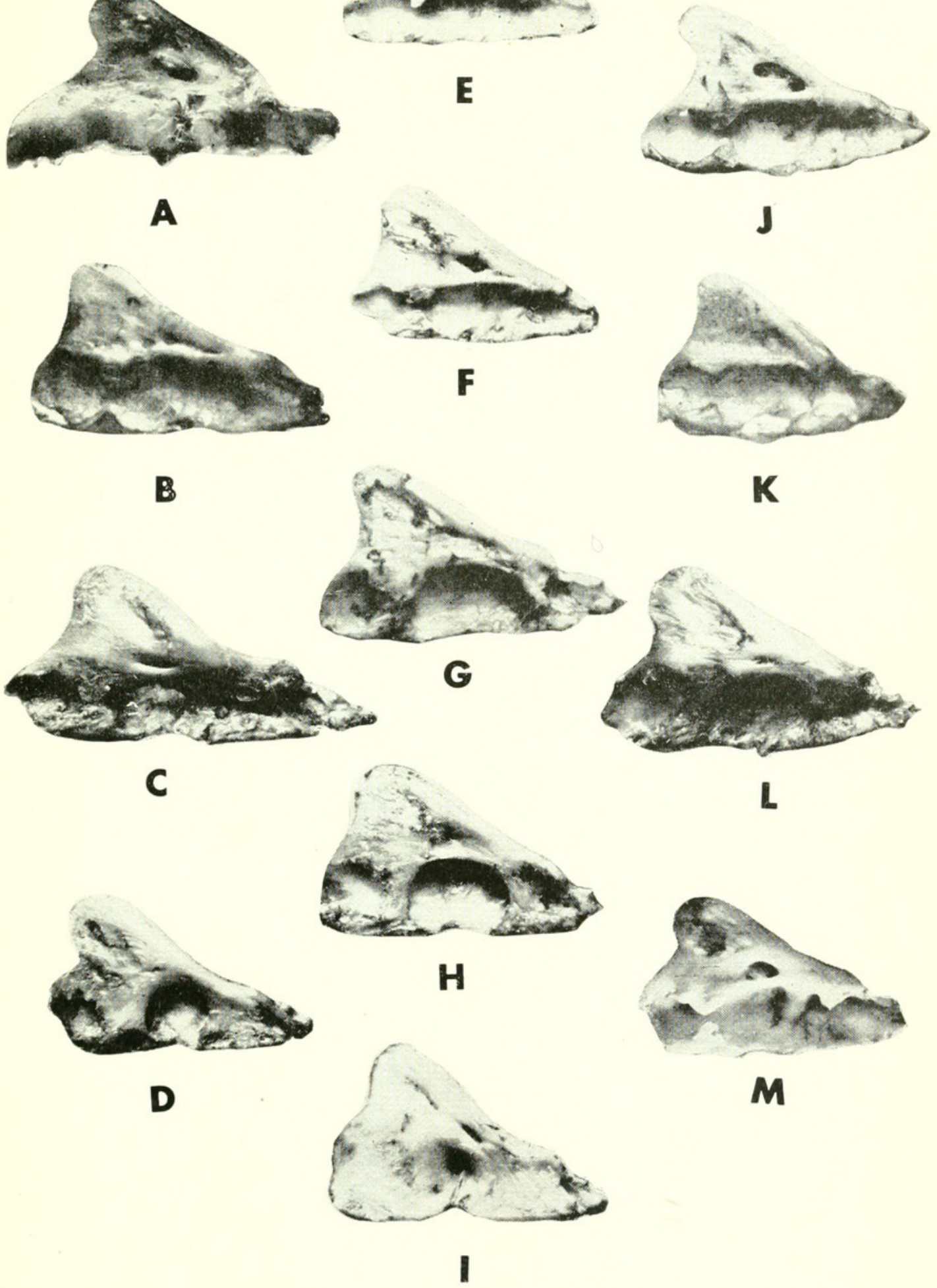

Preorbital bone in 13 species of Conger. A, myriaster; B, oligoporus; c, oceanicus; D, triporiceps; E, orbignyanus; $\mathrm{F}$, esculentus; $\mathrm{G}$, jordani; $\mathrm{H}$, wilsoni, $\mathrm{I}$, cinereus; $\mathrm{J}$, erebennus; $\mathrm{K}$, philippinus; L, conger; $\mathrm{M}$, macrocephalus. Magnification: $\mathrm{F}, \mathrm{L}$, natural size; $\mathrm{C}-\mathrm{E}, \mathrm{H}-\mathrm{J}, \mathrm{M}$, times 2 ; A, G, times 3 ; в, к, times 7 . 

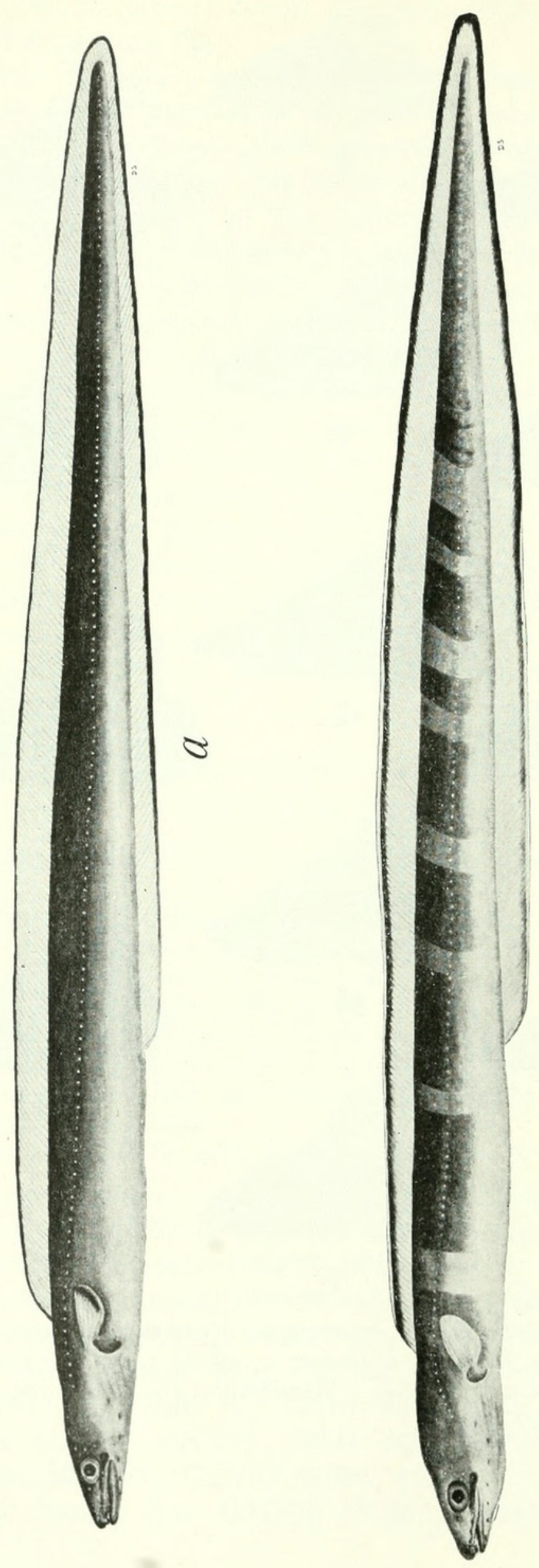

3

든

gn

草

夏

ถี

$\stackrel{\circ}{4}$

$\stackrel{+0}{\Xi}$

$\rightarrow \frac{8}{8}$

ถี

घ

-

प.

5

อ ฐ

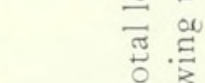

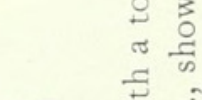

-

朂

$\frac{\pi}{\infty} \frac{ \pm}{m}$

$>$ 茯

$\frac{0}{0} \frac{5}{50}$

i 몽

घ․ㅠ

मे

吾

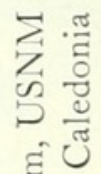

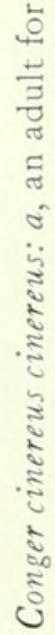



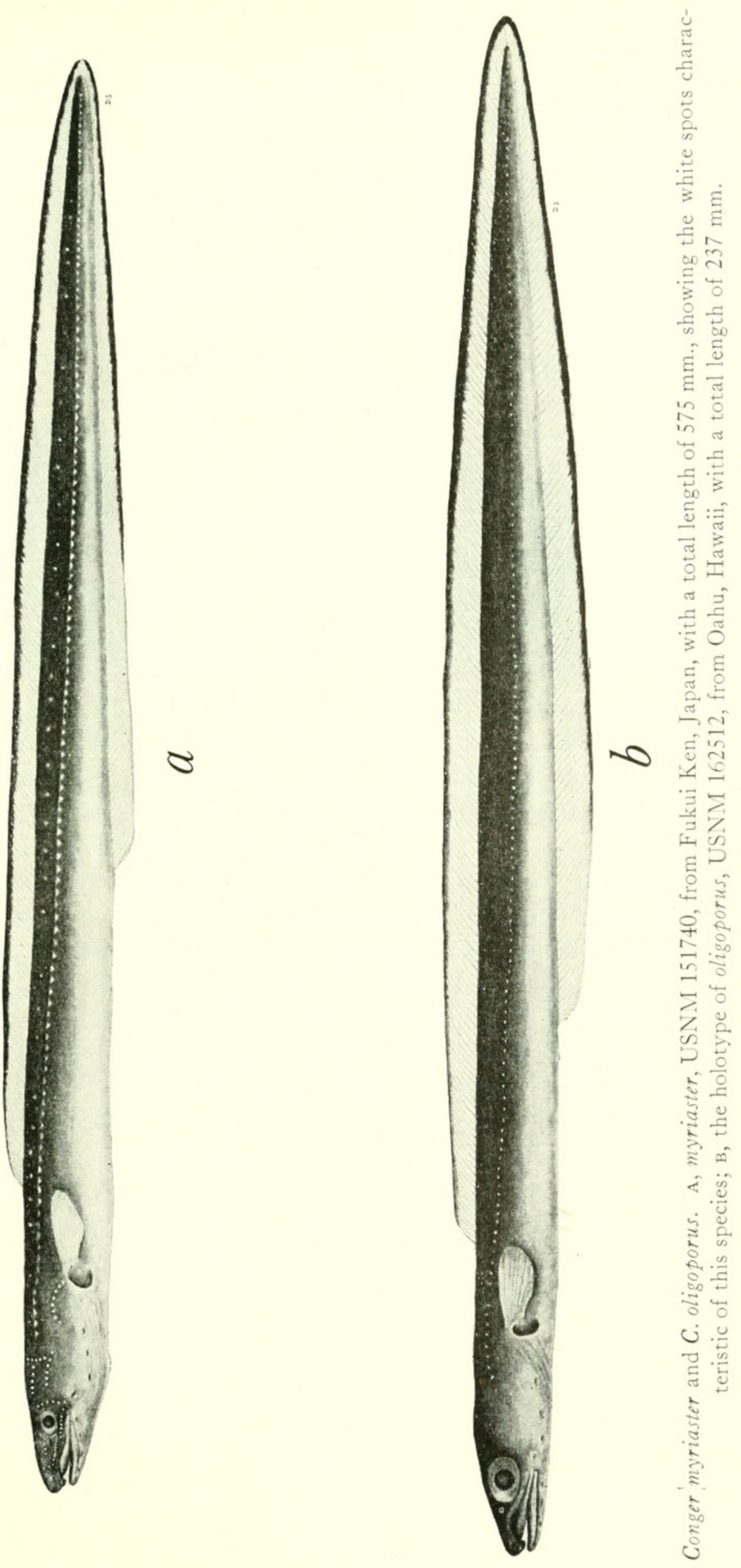

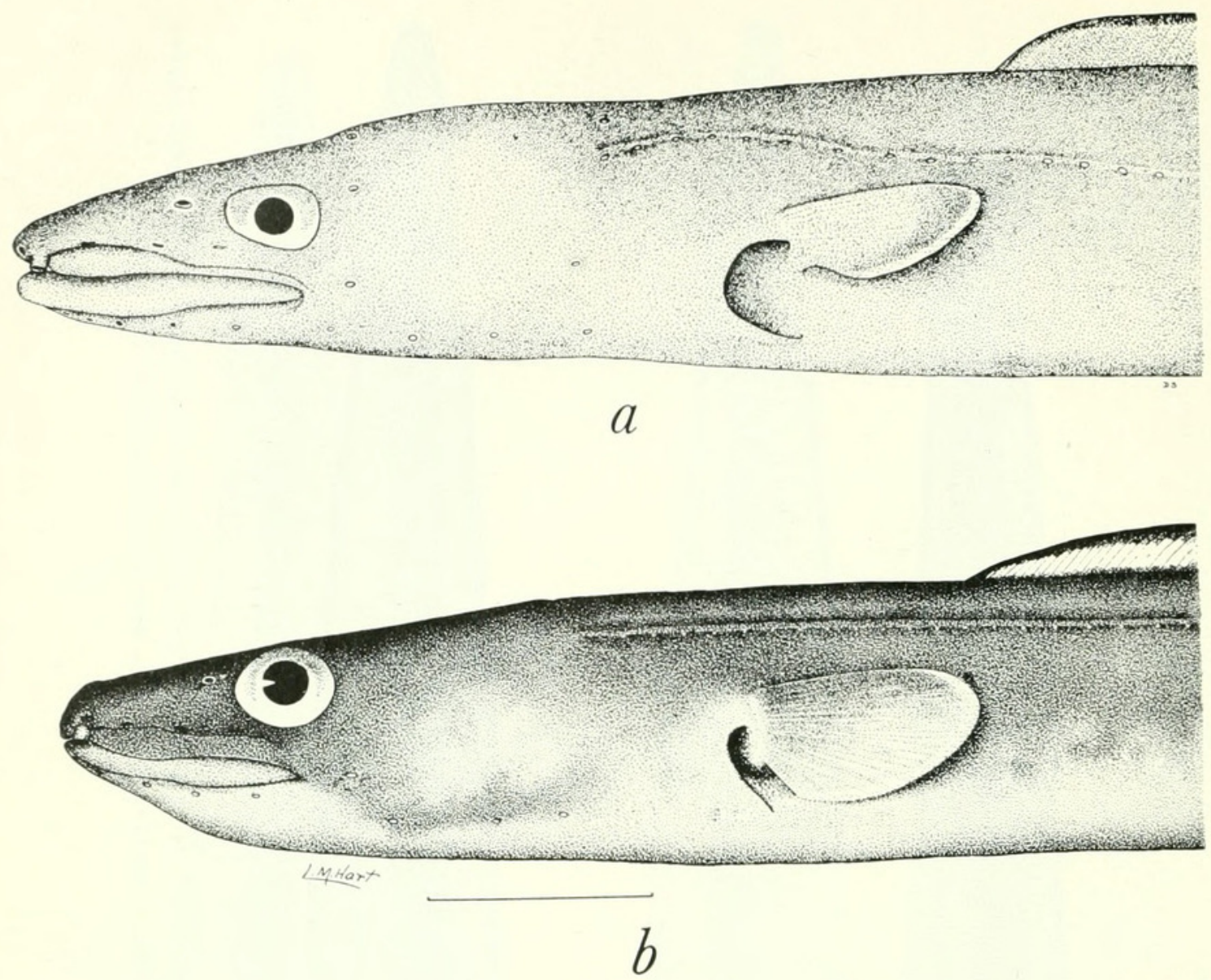

Conger triporiceps and C. erebennus. A, triporiceps, USNM 9792, from Cuba with a total length of $950 \mathrm{~mm}$.; B, holotype of erebennus, SNHM 6166, from Misaki, Japan, with a total length of $483 \mathrm{~mm}$. 
Oigawa 75981; Kobe market USNM 151820 (4), SNHM 30611 (5); Wakanoura SNHM 6968; Nagasaki, UMMZ 165513 (2); Tsushima Straits UMMZ 165533, 165534; Hamada UMMZ 165491, 165536; off Miyazu UMMZ 165519 (3); Wakasa Bay UMMZ 165520 (2); Fukui Ken USNM 151740. Korea: Fusan USNM 163469 (2), UMMZ 165502, 165522 (18). China: Tsingtao, Shantung USNM 130468 (3); Ningpo USNM 130525 (2); Chusan Island SNHM 32422 (3).

Diagnosis: Whitish areas surround the sensory pores and pits on head and body; origin of dorsal fin 8.14 percent behind to 43 percent of pectoral fin in front of pectoral tip; number of compressed teeth 25 to 45 ; least amount of ossification developed in preorbital bone; pores in lateral line 39 to 43 , head length 133 to 160 .

Description: Distance from tip of snout to origin of dorsal fin 172 to 209 ; length of pectoral fin 51 to 70 ; vertebrae 144 to 147 (50 to $56+90$ to 96$)$; in five specimens dorsal fin rays 272 to 287 and anal rays 187 to 218 ; compressed teeth in upper jaw 25 to 45 , in lower jaw 29 to 43 ; generally two rows of teeth laterally in jaws, inner row of teeth from a few teeth to five-sixths the length of outer row; premaxillary tooth-patch wider than long; origin of dorsal fin from 8.14 behind posterior tip of pectorals to 43 percent in front of pectoral tip (table 1); peritoneum silvery to silvery with black specks; ossification not bridging over sensory canal in preorbital bone; white areas around lateral line pores and sensory pits; preorbital bone shows the least ossification when compared to other species. Additional measurements and counts appear in tables 1-6.

Geographical Range: In Japan from Mororan and Hakodate on the Island of Hokkaido southward on the Pacific coast of Japan to Nagasaki, northward to Fukui Ken in the Sea of Japan, to Korea southward to Chekiang Province of China.

Remarks: This species can be distinguished by the white areas surrounding the sensory pores and organs on head and body. In some preserved specimens these white areas are not discernible, thus making this species frequently misidentified with C.jordani. The two species can be distinguished by the number of compressed teeth in upper jaw (table 4) and by the position of the origin of dorsal fin (table 1). The number of pores in lateral line is 39 to 43 , whereas in C. jordani there are 36 to 40 (table 2).

The description of Conger japonica Bleeker (1879, p. 32, pl. 2, fig. 2) gives the number of dorsal rays as 260 , anal 170 ; inner row of teeth of both jaws well developed; Bleeker's illustration shows the dorsal origin slightly in front of pectoral tip. These characters agree with C. myriaster; therefore, I have placed $C$ japonica as a synonym of that species. 


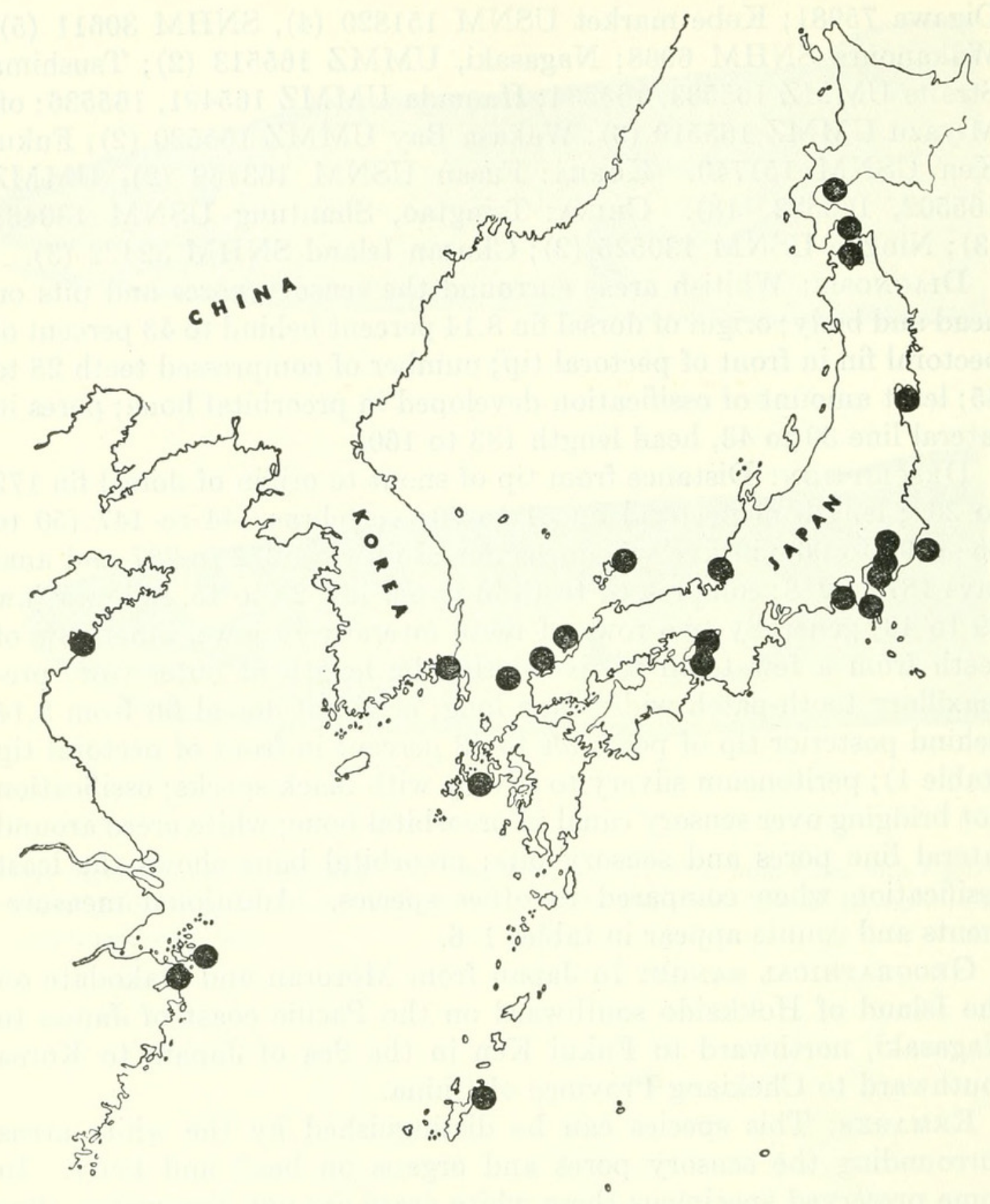

Figure 7.-Distribution of Conger myriaster.

The paratype of Leptocephalus erebennus Jordan and Snyder (SNHM 6968) from Wakanoura is a young specimen of $C$. myriaster.

Dr. Kamohara has been very kind in giving me the description of kiiensis Ui which was not available to me. Following is the translation of the description as transmitted to me. Dorsal fin inserted slightly behind and above posterior end of pectoral fin; caudal long, tapering, acute, head about 5 in its length, head and trunk together a little less than 2 ; back of body pale darkish brown; minute white spots along lateral line; dorsal and anal pale, both fins margined with black posteriorly; total length about $40 \mathrm{~cm}$., rare. 
I am placing this species with $C$. myriaster until the type can be examined.

\section{Conger orbignyanus Valenciennes}

Figures 2, 3, 5; Plate 1,E

Conger orbignyanus Valenciennes, 1847, p. 10, Atlas, pl. 12, fig. 1 (type locality, South America).--Evermann and Kendall, 1906, p. 76.-De Buen, 1950, p. 66. Conger multidens Castelnau, 1855, p. 84, pl. 44, fig. 1 (Rio de Janeiro).-Günther, 1870 , p. 40.

Conger vulgaris Günther, 1870, p. 38 (in part), item " $\mathrm{k}$ " (South America).Perugia, 1891, p. 656 (Montevideo).--Berg, 1895, p. 23 (Mar del Plata, Montevideo).

Conger conger Günther, 1870, p. 13 (La Plata).--Tortonese, 1939, p. 72 (Montevideo).

Leptocephalus conger Jordan and Davis, 1892, p 654 (coast of Brazil).

Leptocephalus orbignyanus Devincenzi, 1924, p. 183 (Banco Inglés, Maldonado, Montevideo).-Devincenzi and Barattini, 1928 pl. 16, fig. 4.-Carvalho, 1943 , p. 43.

Specimens studies: 12 specimens ranging in total length from 603 to $1125 \mathrm{~mm}$., from the following localities: URUGUAY: USNM 87737; Montevideo USNM 22625, SNHM 13492 (2); Rio Plata USNM 86726, MCZ 4701. Argentina: Buenos Aires USNM 55580 (3), SNHM 31617 (2). Brazil: Rio de Janeiro MCZ 4711.

Diagnosis: Pores in lateral line from 44 to 46 ; vertebrae 160-161; origin of dorsal fin one-tenth to 1 pectoral fin length behind posterior tip of pectoral fin; diameter of eye 12 to 17 .

Description: Tip of snout to origin of dorsal fin 178 to 200, length of upper jaw (to rictus) 39 to 52 ; length of pectorals 40 to 51 ; number of compressed teeth in upper jaw 41 to 61 ; in lower jaw 51 to 59 ; vomerine tooth-patch triangular, 30 to 45 teeth; premaxillary tooth-patch wider than long, with 31 to 45 teeth; vertebrae 55 to 56 precaudal, and 106 to 104 caudal (in 2 specimens); 9 or 10 preoperculomandibular pores; a single supratemporal pore; in one specimen dorsal rays 368 , anal 301 ; preorbital bone does not have ossification bridging over sensory canal, pl. 1,E. Additional counts and measurements are recorded in tables $1-3,5,6$ and in figure 2 .

Geographic range: South America, from Uruguay and Argentina northward to Brazil.

Remarks: The distribution of $C$. orbignyanus may ovrleap with that of $C$. triporiceps and $C$. esculentus; however, it can easily be separated by the number of lateral line pores. Also, it may be further distinguished from $C$. triporiceps by the single supratemporal pore and absence of postorbital pores. This species is more closely related to $C$. conger from Europe, but it can be distinguished by the following characters: 
Character

Eye diameter

Head length

Eye into snout

Pectoral rays

Origin of dorsal in relation to pectoral fin tip
C. orbignyanus

12 to 17

122 to 150

2.06 to 2.90 times

16 to 17

one-tenth to 1 pectoral

fin length behind
C. conger

20 to 28

143 to 168

1.36 to 2.11 times

17 to 19

one-fifth in front to one-

third behind

The origin of dorsal fin in relation to pectoral fins in the specimens I have examined are from one-tenth to two-thirds pectoral fin length behind posterior tip of pectoral fin; however, in literature it has been described as 1 pectoral fin length behind.

Dr. E. A. Lachner has examined the type of Conger multidens Castelnau (in the Muséum National d'Histoire Naturelle, Paris, No. $8428), 704 \mathrm{~mm}$. in total length, and states that lateral line pore counts from a vertical from anus anteriorly was 43 on the right side and 45 on the left side, which places this species in the synonymy of $C$. orbignyanus.

\section{Conger conger (Linnaeus)}

Figures 2, 3; Plate 1,L

Muraena conger Linnaeus, 1758, p. 245 (based on Artedi; type locality, Mediterranean Sea).

Conger verus Risso, 1826, p. 201 (Nice).

Conger vulgaris Yarrell, 1831, p. 158.-Bleeker, 1864, p. 26.-Günther, 1870, p. 38 (in part).-Day, $1880-1884$, p. 250.-Moreau, 1881, p. 565.-Stassano, 1890 , p. 32 (Spanish Sahara).-Vinciguerra, 1893, p. 333.-Chabanaud and Monod, 1926, p. 249 (Port-Etienne).-Duncker et al, 1929, p. f.60.

Congrus vulgaris Lowe, 1837, p. 192 (Madeira).-Richardson, 1844-1848, p. 107. Conger rubescens Ranzani, 1840, p. 82, pl. 12.

Leptocephalus conger Fowler, 1912, p. 9 (in part).-Jordan and Gunn, 1899, p. 339. Conger conger Fowler 1923a, p. 33 (Funchal Bay).-Nobre, 1935, p. 383.Cadenat, 1937, p. 437.-Navarro, 1942, p. 196; 1943, p. 125 (Cabo Bojadar, Cabo Blanco).-Fowler, 1936, p. 268 (in part).

Specimens STUdied: 25 specimens, from 83.5 to $87.7 \mathrm{~mm}$. in total length, from the following localities: Sardinia, USNM 143454 (2); Naples, Italy, USNM 48482 (2), 48470, SNHM 20614 (3); Nice, France, MCZ 9326, 9332 (2); Madeira, USNM 6522, SNHM 24032; Azores, USNM 94503; Canary Islands, SNHM 10566, 10586; Bergen, Norway, USNM 17488; Europe, USNM 43123, 43587, MCZ 2554 (4), 2468A (2).

Diagnosis: Pores in lateral line 44 to 47 ; pectoral rays 17 to 20 ; diameter of eye 20 to 28; origin of dorsal fin from 19.30 percent before to 33.74 percent behind pectoral fin tip.

Description: Distance from tip of snout to origin of dorsal fin 186 to 222 ; length of pectorals 37 to 70 ; supratemporal pore 1 ; preoperculomandibular pores 9 ; compressed teeth in upper jaw 25 to 62 , in lower 
jaw 24 to 58 ; 2 rows of teeth laterally in jaws; inner row from onequarter to whole length of outer row; premaxillary tooth-patch wider than long; upper edge of gill opening opposite middle of pectoral fin base; ossification not developed over sensory canal of preorbital bone. Additional counts and proportional measurements are recorded in tables $1-3,5,6$ and in figure 2 .

Geographical Range: Norway southward to Cape Blanco, Africa, and the Canary Islands, throughout the Mediterranean Sea, and occurring in the western half of the Black Sea. Kyle and Ehrenbaum (in Duncker, et al, 1929, p. f.62) state that this species is found as far north as Trondhiem Fjord, Norway, is seldom found in the Baltic Sea in the Kattegat and in the Skaggerak, and is found mainly south and west of the British Isles, in the Biscayne west of Spain, and in the Mediterranean Sea.

Remarks: There may be some population divergence in the Atlantic and Mediterranean forms in regards to snout and head length; however, more specimens are needed to reach definite conclusions. The following tabulations show the comparative snout and head lengths (in thousandth of total length) of the Mediterranean and Atlantic forms:

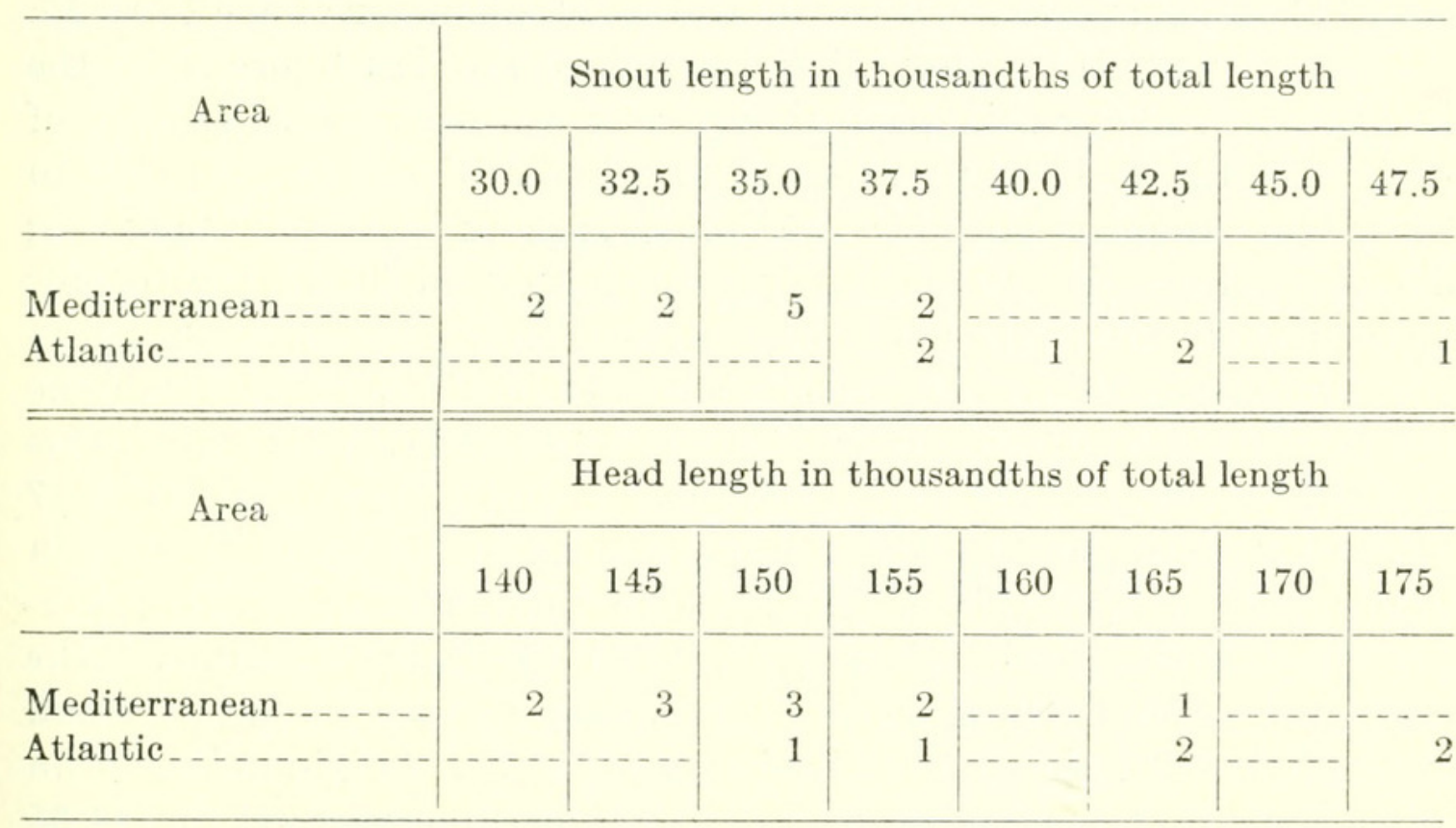

This species is related to C. orbignyanus from the Atlantic coast of South America; however, in $C$. orbignyanus the diameter of eye is smaller, pectoral rays fewer, and origin of dorsal fin more posterior in position. See remarks under $C$. orbignyanus.

Günther (1870, p. 39) records under the species Conger vulgaris a specimen from St. Helena, but this specimen is identified tentatively as C. esculentus. 
Yarrell (1831, p. 158) and subsequent authors based their vulgaris on Anguilla vulgaris Cuvier (1817, p. 231), which is not a Conger but a freshwater eel.

\section{Conger jordani, new species}

Figure 4; Plate 1,G

Leptocephalus erebennus Jordan and Snyder, 1901, p. 849 (in part).

Conger japonicus Jordan and Hubbs, 1925, p. 194 (in part).

[?] Conger vulgaris Barnard, 1925, p. 187 (Agulhas Bank, off South Africa).

[?] Conger conger Smith, 1949, p. 392, fig. 1110 (Cape of Good Hope to Mozambique).

Holotype: USNM 71844, $606 \mathrm{~mm}$. in total length, collected in 1906 at Misaki, Japan, by the Albatross.

PARATyPes: JAPAN: USNM 26250; Misaki USNM 49866, 71843, 71715, 71716, 71845, 72003, 71963, UMMZ 14280, 165503-4, SNHM 12924-5, 23466; Kagoshima USNM 163467; Tokyo market USNM 71818, UMMZ 165537, 165521; Suruga Bay, Shimizu Market UMMZ 165508; Nagasaki UMMZ 165517 (3), 165535; Oкınawa: USNM 71819.

Diagnosis: One row of teeth in jaws; origin of dorsal from 11 to 80 percent of pectoral fin behind posterior tip of pectoral fin; vertebrae 141 to 144 ; pores in lateral line 36 to 40 ; diameter of eye 18 to 26 .

Description: In the following description the first figure is for the holotype; the figures in parentheses refer to paratypes. Length of head 144 (125 to 148); tip of snout to origin of dorsal fin 200 (180 to 217 ); tip of snout to anus 379 (352 to 388 ); snout length 35 (30 to 37); diameter of eye 21 (18 to 26); length of pectoral fin 49 (40 to 56); upper jaw (to rictus) 49 (36 to 51); pores in lateral line 37 to 38 (36 to 40); supratemporal pore 1 ; preoperculo-mandibular pores 9 ; vertebrae 141 to 143 (48 to 50 precaudal, + 92 to 94 caudal); in two specimens dorsal rays 301 and 307 and anal rays 225 and 240 ; pectoral rays 17 (15 to 18); compressed teeth in upper jaw 42 to 77 ; 1 row of teeth in upper jaw, occasionally a few teeth in inner row anteriorly; premaxillary tooth-patch wider than long. In large specimens the ossification of preorbital bone bridges over sensory canal; in small specimens ossification not bridged over $(\mathrm{Pl} .1, \mathrm{G})$. Origin of dorsal fin 28.58 percent of pectoral fin behind posterior tip of pectoral fin (14.65 to 76.95 percent behind pectoral tip). Color notes taken by Dr. C. L. Hubbs for specimen UMMZ 165504 is as follows: Purplish brown fins, blue gray at base and inky black in margin.

Geographical range: From Tokyo Bay southward to Nagasaki, Okinawa, and Africa.

REMARKs: The paratypes of Leptocephalus erebennus Jordan and Snyder (USNM 49866, SNHM 12924 and 12925) are not the same as the holotype of L. erebennus, but are of this new species. 
The affinity of this species is with $C$. oligoporus from Hawaiian waters, but can be distinguished from it by the following characters: The eye smaller, and more vertebrae and more pores in lateral line (see tables 2, 3, 5).

I am unable to distinguish the two specimens from Port Alfred, South Africa, from $C$. jordani, but they are doubtfully included with this species because its geographical distribution is broken considerably from that of $C$. jordani. The origins of dorsal fin of the two African specimens are more anterior in position than in $C$. jordani. The counts and proportional measurements of the two specimens are given below (one specimen had a mutilated head so some of the characters are not given): total length 409 and approximately 635 $\mathrm{mm}$.; pores in lateral line 40 ; pectoral rays 17 and 16 ; vertebrae 144 (X-ray); compressed teeth in upper jaw 42 and 55 , in lower jaw 40 and 56 ; one row of teeth in jaws; a few scattered teeth in inner row; preoperculo-mandibular pores 9 ; supratemporal pore 1 ; dorsal rays 282 ; anal rays 228 ; origin of dorsal fin 24.25 percent behind posterior tip of pectoral fin; preorbital bone bridged over sensory canal; length of head 134 and 144; tip of snout to origin of dorsal fin 176; tip of snout to anus 374 and 386 ; snout length 32 and 40 ; diameter of eye 16 and 21 ; interorbital 21 ; length of upper jaw to rictus 45 ; length of pectoral fin 40; premaxillary tooth-patch wider than long.

Some preserved specimens of $C$. myriaster that lose their white markings around the sensory pores are difficult to distinguish from C.jordani. To separate these specimens see remarks for C. myriaster.

The new species is named for David Starr Jordan, who pioneered in studies of Japanese fishes.

\section{Conger oligoporus, new species}

Plates 1, B, 3, B

Conger wilsoni Fowler, 1923b, p. 375 (Honolulu); 1928, p, 38, pl. 1,c.

Holotype: USNM 162512, $237 \mathrm{~mm}$. in total length, collected Dec. 22, 1951, 5-20 feet in depth at poison station, 200 yards west of Diamond Head Light House, edge of cut in reef, Oahu Island, Hawaii, by Gosline and class.

Paratypes: USNM 163567 (3 specimens), 194, 226, and $245 \mathrm{~mm}$. in total length, taken with the holotype.

George Vanderbilt Equatorial Expedition Stations 15 and 26, 2 specimens, Laysan Island and Maro Reef, Territory of Hawaii, 1951.

Diagnosis: Teeth in one row in jaws, pores in lateral line 35 to 36 , vertebrae 137 to 139 , diameter of eye 24 to 30 . 
Description: The description is based on the holotype and five paratypes. The counts recorded first are for the holotype; those in parentheses are for the paratypes. Pores in lateral line 35 and 36 (35 to 36 ); pectoral rays 15 (16); vertebrae (X-ray) 137 (139); teeth in upper jaw in one row; compressed teeth in upper jaw 40 (30 to 46), in lower jaw 39 (42 to 45), vomerine teeth 13 (12 to 17), premaxillary teeth 16 (12 to 21 ); preoperculo-mandibular pores 9 (9); supratemporal pore 1(1). Gill opening near middle of pectoral base, rictus of jaws extends posteriorly to rear margin of pupil or about twothirds of eye; origin of dorsal fin from 2.63 to 28 percent of pectoral fin length behind posterior tip of pectoral fin. See table 7 for various measurements expressed in thousandths of total length for the holotype and paratypes.

Geographical range: Known only from the Hawaiian Islands.

Remarks: Fowler (1923b, p. 375) recognized two species from the Hawaiian Islands and thought one of his species was the same as Waite's C. wilsoni (=verreauxi); however, it differs from verreauxi in number of lateral line pores and number of vertebrae. Its affinity is with $C$. jordani, but differs from it in that the eye is larger and the number of vertebrae is fewer.

This new species can be distinguised from the two species of Conger in the Hawaiian Islands by the characters given in the key (p. 230).

The name of this new species is in reference to its possession of few lateral line pores.

TABLE 7.-Measurements of Conger oligoporus expressed in thousandths of total length

\begin{tabular}{|c|c|c|c|c|c|c|}
\hline \multirow{2}{*}{ Characters } & \multirow{2}{*}{$\begin{array}{c}\begin{array}{c}\text { Holo- } \\
\text { type }\end{array} \\
\text { USNM } \\
162512\end{array}$} & \multicolumn{5}{|c|}{ Paratypes } \\
\hline & & $\begin{array}{l}\text { USNM } \\
163567\end{array}$ & $\begin{array}{l}\text { USNM } \\
163567\end{array}$ & $\begin{array}{l}\text { USNM } \\
163567\end{array}$ & $\underset{15}{\mathrm{GVF}}$ & $\begin{array}{c}\text { GVF } \\
26\end{array}$ \\
\hline Total length (in mm.) & 237 & 226 & 194 & 245 & 227 & 110 \\
\hline Head length & 143 & 153 & 157 & 145 & 145 & 141 \\
\hline Snout to dorsal origin & 203 & 208 & 219 & 200 & 197 & 200 \\
\hline Snout to anus.......... & 346 & 356 & 379 & 353 & 352 & 341 \\
\hline Snout length & 37 & 36 & 36 & 37 & 35 & 34 \\
\hline Diameter of eye & 27 & 30 & 28 & 28 & 25 & 24 \\
\hline $\begin{array}{l}\text { Length of upper jaw to } \\
\text { rictus }\end{array}$ & 51 & 53 & 54 & 48 & 57 & 45 \\
\hline Pectoral fin length. & 53 & 52 & 59 & 51 & 49 & 45 \\
\hline Depth of body & 49 & 50 & 55 & 43 & 46 & 49 \\
\hline Length of gill opening & 15 & 16 & 17 & 16 & 15 & 14 \\
\hline
\end{tabular}




\section{Conger esculentus Poey}

Figures 2, 3; Plate 1,F

Conger esculentus Poey, 1858, p. 346 (type locality, Cuba); 1867, p. 246; 1868, p. 424; 1876, p. 151.-Stahl, 1883, p. 80.-Rivero, 1938, p. 173.

Conger niger Bean and Dressel, 1884, p. 169 (Jamaica).

[?] Conger vulgaris Günther, 1870, p. 39, item “w," (St. Helena).-Metzalaar, 1919, p. 14 (Curaçao).

[?] Conger vulgaris var. niger Günther 1869, p. 239 (St. Helena).-Melliss, 1875, p. 110 .

Specimens studied: Three specimens, from 970 to $1030 \mathrm{~mm}$. in total length, from the following localities: Cuba, MCZ 9328 (holotype), 9330; Jamaica, USNM 32091.

Diagnosis: Two rows of teeth in jaws; pectoral rays 18 to 19 ; length of head 170 to 183.

Description; Tip of snout to origin of dorsal fin 222 to 236 ; upper jaw 62 ; length of pectorals 59 to 70 ; number of compressed teeth in upper jaw 53 to 63 ; lower jaw 54 to 58 ; vomerine teeth 45 and in a triangular patch; premaxillary teeth 36 ; tooth-patch wider than long; vertebrae 46 precaudal, and 86 caudal; teeth in jaws in two rows; supratemporal pore 1; preoperculo-mandibular pores 9; preorbital bone without ossification bridging across the sensory canal, pl. 1,F. Additional counts and measurements are recorded in tables 1 to 6, and fig. 2. (All counts and measurements of the holotype were made by William C. Schroeder of the Museum of Comparative Zoology at Harvard.)

Geographical Range: Cuba, Jamaica, and possibly to Curaçao and St. Helena.

REMARKs: This species is related to $C$. erebennus from Japan and C. macrocephalus from the Philippines. The differences distinguishing these species are given in the key (p. 230).

Günther (1870, p. 39, item "w") lists under Conger vulgaris an adult from St. Helena. Dr. Marshall of the British Museum kindly furnished the following data for this specimen: Total length $1027 \mathrm{~mm}$; head length $169 \mathrm{~mm}$; tip of snout to anus 428; tip of snout to origin of dorsal fin 259 ; snout length 41 ; eye 21 ; pectoral length 68 ; lateral line pores 37 ; supratemporal pore 1 ; and pectoral rays 16 . The lateral line pore count of 37 for this specimen is much fewer than the usual 44 to 47 for the species $C$. conger from European waters (table 2). The pore counts and proportional measurements are closest to C.esculentus from Cuba. For comparison of the two forms see tables 1, 2, 5,6 . The only difference between the two forms seems to be in the number of pectoral rays-18 to 19 for C.esculentus and 16 for the St. Helena specimen. The number of vertebrae and the number of 
teeth in jaws may show some difference. Until more specimens can be examined I am placing this specimen with $C$. esculentus.

Posada Arango (1909, p. 305) lists Conger vulgaris from the Columbian Caribbean; however, this specimen is not a Conger since it is described with tentacles and barbels. Metzalaar (1919) lists Conger vulgaris from Curaçao. I am unable to verify this specimen as $C$. esculentus, but I am placing it here until it can be verified.

\section{Conger macrocephalus, new species}

Plate 1, M

? Conger vulgaris Bleeker, 1864, p. 26, Java, Celebes and Letti.

? Conger conger Weber and de Beaufort, 1916, p. 259.

Holotype: USNM 164334, total length $803 \mathrm{~mm}$., Philippines, Verde Island passage, lat. $13^{\circ} 34^{\prime} 37^{\prime \prime}$ N., long. $121^{\circ} 07^{\prime} 30^{\prime \prime}$ E., Feb. 22, 1909, collected by the Albatross, at a depth of 180 fathoms.

Diagnosis: Teeth in upper jaws in two rows laterally; pores in lateral line 35; pectoral rays 17; length of head 199.

Description: Length of head 199; tip of snout to origin of dorsal fin 247; tip of snout to anus 416 ; snout length 50 ; diameter of eye 24 length of upper jaw 66 ; length of pectorals 51 ; compressed teeth in upper jaw 66; two rows of teeth in jaws, inner row two-thirds the length of outer row; dorsal rays 288; anal rays 214; premaxillary tooth-patch wider than long; origin of dorsal fin 10.41 percent behind pectoral tip; preorbital bone without ossification bridging across sensory canal; supraorbital pore 1 ; preoperculo-mandibular pores 9; vertebrae 137 (X-ray). Additional counts and proportional measurements are recorded in tables $1,2,3,5,6$.

Geographical Range: Philippines and East Indies.

Remarks: This species is closely related to C.esculentus from the West Indies; however, it differs from it by having fewer pectoral rays and more compressed teeth in upper jaws (table 4). This species is named in reference to its long head.

\section{Conger erebennus (Jordan and Snyder)}

$$
\text { Plates 1,J, 4,B }
$$

Leptocephalus erebennus Jordan and Snyder, 1901, p. 849 (in part), fig. 3 (type locality, Misaki, Japan).

Leptocephalus kiusiuanus Jordan and Snyder, 1901, p. 851 (Hakata, Kiushu, Japan).

Conger japonicus Jordan and Hubbs, 1925, p. 194 (in part).

Specimens studied: Six specimens, ranging in length from 429 to $776 \mathrm{~mm}$., from the following localities: JAPAN: Misaki SNHM 6466 (holotype of erebennus); Hakata, Kiushu SNHM 6467 (type of kiusiuanus); Idzu USNM 22563; Tokyo market USNM 49440; Suruga Gulf USNM 163468. Korea: Fusan USNM 143410. 
Diagnosis: Two rows of teeth in jaws; pectoral rays 19 to 21; origin of dorsal fin from 10 percent behind pectoral tip to 40 percent anterior to pectoral tip; length of head 163 to 184; ossification not bridging across sensory canal of preorbital bone.

Description: Tip of snout to origin of dorsal fin 199 to 222 ; length of pectoral fins 48 to 60 ; upper jaw (to rictus) 52 to 59 ; dorsal rays 288 and 300 , anal rays 217 and 229 in two specimens; vertebrae 137 to 147 (50 precaudal and 87 caudal in one specimen); two rows of teeth in jaws laterally, inner row from one-half to whole length of outer row; 39 to 53 compressed teeth in upper jaw, 40 to 52 in lower jaw; premaxillary tooth-patch wider than long; one supratemporal pore; upper edge of gill opening near midpoint of pectoral base, slightly closer to upper edge than lower; rictus of jaw below middle of eye; length of head into trunk 1.10 to 1.39 , head and trunk into tail 1.48 to 1.60 ; ossification not bridging over sensory canal of preorbital bone. Additional counts and proportional measurements are recorded in tables 1 to 6 . (Counts and measurements of the types were made by Dr. J. Böhlke at Stanford Museum.)

Geographical range: From Sagami Bay southward to Hakata, Kiushu, Japan, to Fusan, Korea.

Remarks: Jordan and Snyder (1901, p. 849) had two other species mixed with the type series of Leptocephalus erebennus: one specimen of Conger myriaster and three of $C$. jordani. Jordan and Snyder recognized the differences in the head and trunk proportions in their key; however, in their description the proportional measurements were mixed.

This species is closely related to C. esculentus from the West Indies. For differences see key (p. 231).

The number of pectoral rays distinguishes this species from the others found in Japanese waters. It differs further from $C$. myriaster by having a longer head and without white areas around sensory pores and pits. It differs further from $C$. jordani by having two rows of teeth in jaws, the origin of dorsal fin situated more anteriorly, and ossification not bridging over sensory canal of the preorbital bone.

Conger philippinus, new species

Plate 1, K

[?] Conger vulgaris Günther, 1870, p. 39 (in part), item "l" (East Indian Archipelago).

[?] Conger multidens Pohl, 1884, p. 40 (fide Fowler, 1931, p. 316, Viti Levu).Whitley, 1927, p. 4.

[?] Conger orbignyanus Fowler, 1931, p. 316.

Conger conger Herre, 1934, p. 16 (Cebu, Dumaguete, and Oriental Negros in the Philippines).

Holotype: USNM 134969, $234 \mathrm{~mm}$. in total length, collected at a market in Cebu, Philippines, Mar. 22, 1909, Albatross. 
Paratypes: SNHM 27116, 223 mm., from Cebu, Philippines, Aug. 27, 1931, Herre; SNHM 26848 (2), 212 and 278 mm., Dumaguete, Philippines, June 18, 1931, Herre's Philippine Expedition.

Diagnosis: Two rows of teeth laterally, pores in lateral line 37 to 38 ; vertebrae 127 to 135 ; pectoral rays 15 to 16 .

Description: The counts recorded first are for the holotype; those in parentheses are for the paratypes. Length of head 124 (126 to 144); tip of snout to origin of dorsal fin 201 (202 to 224); tip of snout to anus 359 (363 to 401); snout length 27 (27 to 34); diameter of eye 20 ( 22 to 26 ) ; length of pectoral fins 46 (47 to 50); upper jaw (to rictus) 39 (41 to 50); supratemporal pore 1; pores in lateral line 38 (37 to 38 ); preoperculo-mandibular pores 9 ; vertebrae 130 (127 to 135); pectoral rays 16 (15 to 16 ); compressed teeth in upper jaw 38 to 45 ; two rows of teeth laterally in jaw; premaxillary tooth-patch wider than long; origin of dorsal fin 75 percent of pectoral fin length behind posterior tip of pectoral fin (71.43 percent to 85.00 percent); preorbital bone without ossification bridging across sensory canal at 278 $\mathrm{mm}$. in total length.

Geographical Range: Philippine Islands, East Indies, and possibly Fiji Islands.

REMARKs: This species is related to $C$. wilsoni from Australian waters; however, it differs from it by having fewer lateral line pores, pectoral rays and vertebrae.

Pohl (1884, p. 40, fide Fowler, 1931, p. 316) records a specimen of Conger multidens from the Fiji Islands with origin of dorsal fin about a pectoral fin length behind posterior tip of pectoral fin; however, until a specimen can be examined from that area I am referring it to this species.

Dr. Marshall of the British Museum has measured and made counts on a specimen listed under Conger vulgaris by Günther (1870, p. 39, item "l".) The counts and measurements compare closely with philippinus.

\section{Conger wilsoni (Bloch and Schneider)}

Figure 2,w; Plate 1, H

Gymnothorax wilsoni Bloch and Schneider, 1801, p. 529 (type locality, New Holland).

Conger wilsoni Castelnau, 1872, p. 193 (Hobart, Tasmania, and Hobson's Bay, Victoria).-Waite, 1923, p. 72, fig. 54 .

Leptocephalus monganius Phillipps, 1932, p. 230 (Mongoniu, Doubtless Bay).

Leptocephalus labiatus Griffen, 1936, p. 15.

Leptocephalus wilsoni hesperius Whitley, 1944, p. 25, fig. 1, (Leighton Beach, near Fremantle, Western Australia).

Specimens studied: Four specimens, ranging in length from 289 to $1012 \mathrm{~mm}$., from the following localities in Australia: Port Jackson, New South Wales, USNM 47765, 47830, and 47764; Strickland Bay, Rottnest Island, Western Australia, USNM 164518. 
Diagnosis: Two rows of teeth in jaws, lateral line pores 38 to 40, pectoral rays 17 to 18 , vertebrae 146 to 147 .

Description: Tip of snout to origin of dorsal fin 185 to 194 ; length of head 119 to 139 ; tip of snout to anus 349 to 379 ; diameter of eye 15 to 23 ; length of snout 26 to 34 ; length of upper jaw (to rictus) 40 to 46 ; length of pectoral fin 42 to 47 ; supratemporal pore 1 ; preoperculomandibular pores 9; vertebrae 146 to 147 (50 to 51 precaudal plus 95 to 96 caudal); vomerine teeth 25 to 46 ; premaxillary teeth 12 to 36 ; two rows of teeth in jaws laterally; premaxillary tooth-patch wider than long; preorbital bone has ossification developed across sensory canal (pl. 1,H); origin of dorsal fin from 26 percent to 71.5 percent of pectoral fin behind posterior tip of pectoral fin. Additional counts and proportional measurements are recorded in tables 1-6.

Geographical Range: From Moreton Bay, Queensland, southward to Tasmania and New Zealand, and westward to Fremantle, Western Australia.

Remarks: This species is related to $C$. oceanicus but differs in the origin of dorsal fin being more posterior in position and by having a greater number of compressed teeth in upper jaw (fig. 2).

Griffen (1936) in his revision of the eels of New Zealand, lists 2 species from that area and distinguishes the 2 species by the origin of dorsal fin and the thickness of the body.

\section{Conger verreauxi Kaup}

Conger verreauxi Kaup, 1856a, p. 72 (type locality Australia).

Conger vulgaris Günther, 1870, p. 39, items " $\mathrm{x}$ " and " $y$," (Tasmania).

[?] Conger labiata Castelnau, 1879, p. 396 (Port Jackson, New South Wales).

Leptocephalus conger Waite, 1911, p. 164 (between Timaru and Porangahan Bay on east cost of New Zealand).

Leptocephalus labiatus Phillipps, 1932, p. 229, fig. 3.

Leptocephalus verreauxi Griffen, 1936, p. 15.

Conger wilsoni Waite, 1921, p. 49, fig. 74; 1923, p. 72, fig. 54.

Specimens studied: A specimen in the British Museum, examined by Dr. Marshall, and Kaup's type from the original description.

Diagnosis: Two rows of teeth in jaws; vertebrae 152 to 156 ; origin of dorsal fin about over the posterior tip of pectoral fin; diameter of eye small.

Description: Length of head 131 to 143 ; tip of snout to origin of dorsal fin 202; tip of snout to anus 377 to 412 ; snout length 39 ; diameter of eye 11; length of pectorals 39 to 59 ; origin of dorsal fin 9.43 percent of pectoral fin behind posterior tip of pectoral fin forward; two rows of teeth in jaws laterally, 54 to 55 precaudal and 97 to 102 caudal vertebrae. Additional counts and proportional measurements are recorded in tables $1-3,5,6$. 
Geographical range: From southern Queensland southward to Tasmania and New Zealand.

Remarks: In the English translation, Kaup's (1856b, p. 115) locality of the type specimen of Conger verreauxi was omitted. Kaup's description (1856b, p. 73) states "nach meinen verehrten Freunde Julius Verreaux genannt, welcher ihn in Australien sammelte." Whitley (in Griffen, 1936, p. 15) thinks that the type probably came from Tasmania, where Verreaux collected.

Castelnau (1879, p. 396) and Phillipps (1932, p. 229) mention a small tentacle on each side of the snout; if this is so, C. verreauxi is the only species in the genus that has such tentacles.

There are two species of Conger in Australian waters. The main difference between them appears to be in the number of vertebrae and the origin of the dorsal fin, which is in a more anterior position in C. verreauxi.

\section{Conger oceanicus Mitchell}

Figures 2,3 ; Plate 1 , C

Anguilla conger Mitchell, 1814, p. 360.

Anguilla oceanica Mitchell, 1818, p. 407 (type locality, off New York, near Bloch Island).-Storer, 1846, p. 234.

Conger occidentalis De Kay, 1842, p. 314, pl. 53, fig. 172.

Isognatha oceanica Gill, 1861, p. 56.

Echelus conger Jordan, 1888, p. 90.

Leptocephalus conger Jordan and Davis, 1892, p. 664 (in part).- Jordan and Evermann, 1896, p. 354 (in part), pl. 57, fig. 148.-Smith, 1907, p. 111, fig. 35.Fowler, 1912, p. 9 (in part).

Conger conger Bigelow and Welsh, 1925, p. 86, fig. 36.-Hildebrand and Schroeder, 1928, p. 116.-Jordan, Evermann and Clark, 1930, p. 79 (in part).

Conger oceanica Bigelow and Schroeder, 1953, p. 154, fig. 70.

Specimens studied: 48 specimens, ranging in total length from 152 to $1052 \mathrm{~mm}$., from the following localities: Massachusetts, USNM 16961, 49682, 126121, 148152 (2) MCZ 35806; Connecticut, USNM 16027, 43098, 14053 (2); Rhode Island, USNM 20745; New York, USNM 48941; New Jersey, USNM 6827, 28717, 28765, 33053, 36908 , 118205 thru 118210 (7); Virginia, USNM 32796-7-8, 90395; Chesapeake Bay, USNM 127218; North Carolina, USNM 131327, 134184, CNHM 39999, 40000, 40331, AMNH 4369 (3), SNHM 1880; South Carolina, USNM 7418, 25352, 25358, SNHM 10314; Florida (New Smyrna), USNM 62652; Mississippi, USNM 164239 (4); Atlantic Coast of United States, USNM 44341.

Diagnosis: Pores in lateral line 39 to 44 ; pectoral rays 16 to 18 ; vertebrae 140 to 147 ; diameter of eye 17 to 28 .

Description: Tip of snout to origin of dorsal fin 185 to 230 ; length of pectoral fins 37 to 62 ; supratemporal pore 1; preoperculo- 
mandibular pores 9 ; vertebrae 85 to 96 caudal and 50 to 51 precaudal; in one specimen dorsal rays 273 ; anal rays 187 ; compressed teeth in upper jaw 27 to 65 , in lower jaw 28 to 59 ; two rows of teeth in jaws, inner row conical; premaxillary tooth-patch wider than long; upper edge of gill opening near midpoint of pectoral fin base; rictus of jaw below middle of eye. Additional counts and proportional measurements are recorded in tables $1-3,5,6$, and in figure 2 .

Distribution: On eastern Atlantic coast from Massachusetts to Florida, and Gulf of Mexico to Pascagoula, Miss. Bigelow and Schroeder (1953, p. 156) record adults from North Truro, Cape Cod, and near Provincetown in Cape Cod Bay, Mass. The Oregon collected four specimens just south of Pascagoula, Miss., at a depth of 260 fathoms in an 80-foot balloon trawl.

Remarks: There is a clinal difference in the length of head and snout from north to south. The forms from New England have a shorter head and snout than those of Carolinas and Florida; those from the Gulf of Mexico have the longest.

\begin{tabular}{|c|c|c|c|c|c|c|c|c|c|c|c|}
\hline \multirow{2}{*}{ Area } & \multicolumn{11}{|c|}{ Length of head in thousandths of total length } \\
\hline & 130 & 135 & 140 & 145 & 150 & 155 & 160 & 165 & 170 & 175 & 180 \\
\hline New England States.. & 1 & 1 & 3 & 1 & 2 & 3 & 1 & & & & \\
\hline New Jersey-Virginia _... & $-\ldots$ & 1 & 3 & 5 & 2 & 3 & 1 & 3 & & & - \\
\hline $\begin{array}{l}\text { North Carolina south- } \\
\text { ward }\end{array}$ & & & & 2 & 1 & 3 & 3 & 3 & 5 & 1 & \\
\hline Gulf of Mexico $\ldots \ldots$ & $-\ldots$ & & & $-\ldots$ & $-\ldots$ & 1 & & 1 & 1 & $-\ldots$ & 1 \\
\hline
\end{tabular}

\begin{tabular}{|c|c|c|c|c|c|c|c|c|c|}
\hline \multirow{2}{*}{ Area } & \multicolumn{9}{|c|}{ Length of snout in thousandths of total length } \\
\hline & $\begin{array}{l}27.5- \\
29.9\end{array}$ & $\begin{array}{l}30.0 \\
32.4\end{array}$ & $\begin{array}{l}32.5- \\
34.9\end{array}$ & $\begin{array}{l}35.0 \\
37.4\end{array}$ & $\begin{array}{l}37.5- \\
39.9\end{array}$ & $\begin{array}{l}40.0 \\
42.4\end{array}$ & $\begin{array}{l}42.5 \\
44.9\end{array}$ & $\begin{array}{l}45.0 \\
4 \% .4\end{array}$ & $-\begin{array}{l}47.5- \\
49.9\end{array}$ \\
\hline New England States.... & 2 & 3 & 1 & 3 & 1 & 1 & & & \\
\hline New Jersey-Virginia & 1 & 4 & 4 & 2 & 4 & 4 & & & \\
\hline $\begin{array}{l}\text { North Carolina south- } \\
\text { ward }\end{array}$ & $-\ldots$ & 1 & 2 & 1 & 4 & 3 & 3 & & \\
\hline Gulf of Mexico & $\ldots$ & & - - - - & & $\ldots$ & 2 & $\ldots$ & & 2 \\
\hline
\end{tabular}

This species is related to $C$. wilsoni from Australia, but differs from it by having the origin of dorsal fin more anterior in position and a fewer number of compressed teeth in the upper jaw (fig. 2). 


\section{References}

Allis, E. P.

1903. The lateral sensory system in the Muraenidae. Inter. Monat. Anat. Physiol., vol. 20, pp. 125-170, plates.

Aoyagi, Hyozi

1943. Coral fishes. Pt. 1, xii +224 pp., 54 figs., 37 pls.

Barnard, K. H.

1925. A monograph of the marine fishes of South Africa. Pt. 1. Ann.

South African Mus., vol. 21, 418 pp., 18 text-figs., 17 pls.

Bean, Tarleton H., and Dressel, H. L.

1884. A catalogue of fishes received from the public museum of the Institute of Jamaica, with descriptions of Pristipoma approximans and Tylosurus euryops, two new species. Proc. U. S. Nat. Mus., vol. 7, No. 418, pp. 151-170.

Berg, Carlos

1895. Enumeración sistemática y sinonímica de los peces de las Costas Argentina y Uruguaya. Anal. Mus. Nac. Buenos Aires., vol. 4, pp. 1-120, 1 pl.

Bigelow, Henry B., and Schroeder, William C.

1936. Supplemental notes on fishes of the Gulf of Maine. Bull. U. S. Bur. Fish., vol. 48, pp. 319-343.

1953. Fishes of the Gulf of Maine. U. S. Fish \& Wildlife Serv., Fish Bull. 74 , vol. 53, 577 pp., 288 figs.

Bigelow, Henry B., and Welsh, William W.

1925. Fishes of the Gulf of Maine. Bull. U. S. Bur. Fish. (1924), vol. 40, pt. 1., 567 pp., 278 figs.

Bleeker, Pieter

1857. Achtste bijdrage tot de kennis der vischfauna van Amboina. Acta Soc. Sci. Indo-Néerl., vol. 2, pp. 1-102.

1864. Atlas ichthyologique des Indes Orientales Nêêrlandaises. Vol. 4, 132 pp., pls. $145-193$.

1879. Enumération des espèces de poissons actuellement connues du Japon et description de trois espèces inédites. Verh. Konink. Acad. Weten., Amsterdam, vol. 18, pp. 1-33, 3 pls.

Bloch, Marc Elieser, and Schneider, Johann Gottlob

1801. M. C. Blochii . . . Systema Ichthyologiae iconibus ex illustratum. Post obitum auctoris opus inchoatum absolvit, correxit, interpolavit Jo. Gottlob Schneider. $1 \mathrm{x}+584$ pp., 110 col. pls.

Boeseman, Marinus

1947. Revision of the fishes collected by Burger and Von Siebold in Japan. Zool. Mededeelinger, Leiden, vol. 28, 242 pp., 5 pls.

Bosc, L. A. G.

1817. Nouveau dictionnaire d'histoire naturelle. Vol. 7, 586 pp., pls.

Brevoort, James Carson

1856. Notes on some figures of Japanese fish. In Narrative of the expedition . . . to the China Seas and Japan . . . in . . . 1852-54, under the command of Commodore M. C. Perry. Vol. 2, pp. 253288,9 pls.

Cadenat, J.

1937. Recherches systématiques sur les poissons littoraux de la côte occidentale d'Afrique récoltés par le navire "President-TheodoreTissier" au cours de sa V Croissiere (1936). Rev. Trav. Off. Pêches Marit., vol. 10, pp. 425-562. 
Carvalho, J. Paiva

1943. Nota preliminar sobre a fauna ictiologica do littoral Sul do Estado de São Paulo. Bol. Indust. Animal, No. 150, pp. 27-81.

Castelnau, (Comte) François L. de Laporte de

1855. Expedition dan les parties centrales de l'Amerique du Sud, de Rio de Janeiro à Lima, et de Lima au Para; executée . . . pendant les années 1843 a 1847 . . , vol. 3, Poissons, xii+112 pp., 50 col. pls.

1872. Contribution to the ichthyology of Australia. Proc. Zool. Acclim. Soc. Victoria, vol. 1, pp. 29-247.

1879. Essay on the ichthyology of Port Jackson. Proc. Linn. Soc. New South Wales, vol. 3, pt. 4, pp. 347-402.

Chabanaud, P., and Monad, T.

1926. Les poissons de Port-Etienne. Bull. Com. Etúd. Hist. Sci. Afrique Occidentale Française, pp. 225-287, 33 figs.

Cuvier, G. L. C. F. D.

1817. Le règne animal . . ., ed. 1, vol. 2, 532 pp.

1834. The animal kingdom . . . Translated from the last French edition, with additional notes. . ., vol. 2 , xvi+412 pp.

DaY, Francis

1880- The fishes of Great Britain and Ireland, vol. 2, 388 pp.

1884 .

De Buen, Fernando

1950. El mar de solis y su fauna de peces. (Pt. 2). La fauna de peces del Uruguay. Publ. Cient. Serv. Oceanogi. Pesca No. 2, pp. 46-144.

De Kay, James Ellsworth

1842. In Zoology of New York. Pt. 4, Fishes. xiv +415 pp., 79 pls., 250 figs.

Devincenzi, Garibaldi J.

1924. Peces del Uruguay. Anales Mus. Hist. Nat. Montevideo, ser. 2, vol. 1, No. 5, pp. 139-290.

Devincenzi, Garibaldi J., and Barattini, Luis P.

1928. Album ictiologico del Uruguay. Anales Mus. Hist. Nat. Montevideo, ser. 1 and 2, (Supplement to ser. 2, vol. 2), pls. 1-24.

Duncker, G.; Ehrenbaum, E.; Kyle, H. M.; Mohr, E. W.; and SchnakenBECK, W.

1929. Die Fische der Nord-und Ostsee, teil XII, pp. c3-h202, 377 figs., $1 \mathrm{pl}$.

Evermann, Barton Warren, and Kendall, William Converse

1906. Notes on a collection of fishes from Argentina, South America, with description of three new species. Proc. U. S. Nat. Mus., vol. 31, No. 1482 , pp. 67-108, 4 figs.

Fowler, Henry W.

1912. Description of nine new eels, with notes on other species. Proc. Acad. Nat. Sci. Philadelphia, vol. 64, pp. 8-39, 9 figs.

1923a. Fishes from Madeira, Syria, Madagascar and Victoria, Australia. Proc. Acad. Nat. S.i. Philadelphia, vol. 75, pp. 33-45.

1923b. New or little known Hawaiian fishes. Occ. Pap. Bernice P. Bishop Mus. Poly. Ethn. Nat. Hist., vol. 8, No. 7, pp. 375-392.

1928. Fishes of Oceania. Mem. Bernice P. Bishop Mus., vol. 10, iii +540 pp., 49 pls., 82 figs.

1931. The fishes of Oceania. Supplement 1. Mem. Bernice P. Bishop Mus., vol. 11, No. 5, pp. 313-381, 7 figs. 
1934. The fishes of Oceania. Supplement 2. Mem. Bernice P. Bishop Mus., vol. 11, No. 6, pp. 385-466, 4 figs.

1936. The marine fishes of West Africa based on the collection of the American Museum Congo expedition, 1909-1915. Bull. Amer. Mus. Nat. Hist., vol. 70, pt. 1, 605 pp., 275 figs.

1938. The fishes of the George Vanderbilt South Pacific Expedition, 1937. Acad. Nat. Sci. Philadelphia Monogr. No. 2, 349 pp., 12 pls., 1 map.

1944a. Results of the fifth George Vanderbilt Expedition (1941), Fishes. Acad. Nat. Sci. Philadelphia Monogr. No. 6, pp. 57-529, 20 pls., 265 figs.

1944b. Fishes obtained in the New Hebrides by Dr. Edward L. Jackson. Proc. Acad. Nat. Sci. Philadelphia, vol. 96, pp. 155-199, 35 figs.

1953. The shore fishes of the Columbian Caribbean. Caldasia, vol. 6, No. 27 , pp. $43-73$.

Gill, Theodore N.

1861. Catalogue of the fishes of the eastern coast of North America from Greenland to Georgia. Proc. Acad. Nat. Sci. Philadelphia (1862), pp. 1-63.

1873. Catalogue and bibliography of the fishes of the east coast of North America. Rep. U. S. Fish Comm. for 1871-72, pt. 1, pp. 779-822.

Ginsburg, IsaAC

1951. The eels of the northern Gulf coast of the United States and some related species. Texas Journ. Sci., vol. 3, pp. 431-485, 16 figs.

Griffen, L. T.

1936. Revision of the eels of New Zealand. Trans. Roy. Soc. New Zealand, vol. 66 , pt. 1, pp. 12-26, pls., 5, 6, text-figs. 1-6.

Günther, Albert

1869. Report of a second collection of fishes made at St. Helena by J. C. Mellis. Esq. Proc. Zool. Soc., London, pp. 238-239.

1870. Catalogue of the fishes in the British Museum, vol. 8, xxv +549 pp. Herre, A. W.

1934. Notes on fishes in the zoological museum of Stanford University. I. The fishes of the Herre Philippine Expedition of 1931, Hong Kong, $106 \mathrm{pp}$.

Hildebrand, Samuel F., and Schroeder, William C.

1928. Fishes of Chesapeake Bay. Bull. U. S. Bur. Fish. (1927), vol. 43, pt. 1, 366 pp., 211 figs.

Hubbs, Carl L., and Hubbs, Clark

1953. An improved graphical analysis and comparison of series of samples. Syst. Zool., vol. 2, No. 2, pp. 49-56, 92.

Jenkins, J. Travis.

1925. The fishes of the British Isles. $408 \mathrm{pp}$.

Jordan, David Starr

1888. Manual of the vertebrate animals of the northern United States. Ed. 5 , iii +375 pp.

Jordan, David Starr, and Davis, Bradley Moore

1892. A preliminary review of the apodal fishes or eels inhabiting the waters of America and Europe. Rep. U. S. Comm. Fish and Fisheries for 1888 , pt. 16 , appendix No. 10 , pp. $581-678$, pls. $73-80$.

Jordan, David Starr, and Evermann, Barton Warren

1896. Fishes of North and Middle America. U. S. Nat. Mus. Bull. 47, pt. 1, $1240 \mathrm{pp}$. 
1905. The shore fishes of the Hawaiian Islands with a general account of the fish fauna. Bull. U. S. Fish Comm. (1903), vol. 23, pt. 1, xxviii+ 574 pp., 73 col. pls., 65 pls., 228 figs.

Jordan, David Starr; Evermann, Barton Warren; and Clark, Howard WALTON.

1930. Check list of the fishes and fishlike vertebrates of North and Middle America north of the northern boundary of Venezuela and Colombia. Rep. U. S. Comm. Fish. (1928), pt. 2, 670 pp.

Jordan, David Starr, and Gilbert, Charles H.

1882. List of a collection of fishes made by Mr. L. Belding near Cape San Lucas, lower California. Proc. U. S. Nat. Mus., vol. 5, pp. 378-381. Jordan, David Starr, and Gunn, James Alexander Jr.

1899. List of fishes collected at the Canary Islands by Mr. O. F. Cook, with descriptions of four new species. Proc. Acad. Nat. Sci. Philadelphia (1898), pp. 339-346.

Jordan, David Starr, and Hubbs, Carl Leavitt

1925. Record of fishes obtained by David Starr Jordan in Japan, 1922. Mem. Carnegie Mus., vol. 10, No. 2, pp. 93-346, pls. 5-12.

Jordan, David Starr, and Snyder, John Otterbein

1901. A review of the apodal fishes or eels of Japan, with description of nineteen new species. Proc. U. S. Nat. Mus., vol. 23, No. 1239, pp. 837-890, 22 figs.

Kamohara, ToshiJi

1950. Description of the fishes from the Provinces of Tosa and Kishu, Japan. $3+288+5+48+27$ pp., 220 figs.

KaUp, JohanN JACOB

1856a. Uebersicht der Aale. Arch. Naturg., vol. 22, pt. 1, pp. 41-77.

1856b. Catalogue of apodal fish in the collection of the British Museum, London, 163 pp., 19 pls.

Klunginger, Carl Benjamin

1871. Synopsis der fische des Rothen Meeres. II. Verh. Zool. Bot. Ges. Wien, vol. 21, pp. 441-668.

Linnaeus, Carl

1758. Systema naturae . . . , ed. 10, vol. 1, 824 pp.

Lowe, R. T.

1837. A synopsis of the fishes of Madeira, with the principal synonyms, Portuguese names and characters of the new genera and species. Trans. Zool. Soc. London, vol. 2, pt. 3, pp. 173-200.

Matsubara, Kiyomatsu

1955. Fish morphology and hierarchy. Ishizaki-Shoten, Tokyo, pt. 1, $\mathrm{xi}+789 \mathrm{pp}$.

Meek, Seth E., and Hildebrand, Samuel F.

1923. The marine fishes of Panama. Field Mus. Nat. Hist., Zool. ser.,

Melliss, John Charles vol. 15, pt. 1, 330 pp., 24 pls.

1875. St. Helena . . . P. Pp. 100-113, pls. 19-21.

MetzalaAR, J.

1919. Report on the fishes collected by Dr. J. Boeke, in the Dutch West Indies, 1904-1905, with comparative notes on marine fishes of tropical West Africa. In Boeke, Rapport betreffende . . . toestand . . . Visscherij . . . Zeeproducten in de Kolonie Curacao . . . 1904, 315 pp., 64 figs. 


\section{$2 \mathrm{BHL}$ Biodiversity Heritage Library}

Kanazawa, Robert H. 1958. "A revision of the eels of the genus Conger with descriptions of four new species." Proceedings of the United States National Museum 108(3400), 219-267. https://doi.org/10.5479/si.00963801.108-3400.219.

View This Item Online: https://www.biodiversitylibrary.org/item/32559

DOI: https://doi.org/10.5479/si.00963801.108-3400.219

Permalink: https://www.biodiversitylibrary.org/partpdf/7089

\section{Holding Institution}

Smithsonian Libraries

\section{Sponsored by}

Smithsonian

\section{Copyright \& Reuse}

Copyright Status: NOT_IN_COPYRIGHT

Rights: https://www.biodiversitylibrary.org/permissions/

This document was created from content at the Biodiversity Heritage Library, the world's largest open access digital library for biodiversity literature and archives. Visit BHL at https://www.biodiversitylibrary.org. 